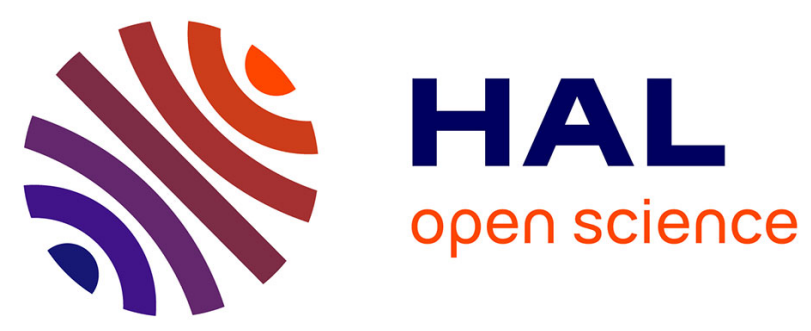

\title{
Energy and lipid metabolism gene expression of D18 embryos in dairy cows is related to dam physiological status
}

\author{
Damien Valour, Severine Degrelle, Andrew A. A. Ponter, Corinne \\ Giraud-Delville, Evelyne Campion, C Guyader-Joly, Christophe Richard, \\ Fabienne F. Constant, P Humblot, C Ponsart, et al.
}

\section{To cite this version:}

Damien Valour, Severine Degrelle, Andrew A. A. Ponter, Corinne Giraud-Delville, Evelyne Campion, et al.. Energy and lipid metabolism gene expression of D18 embryos in dairy cows is related to dam physiological status. Physiological Genomics, 2014, 46 (2), pp.39-56. 10.1152/physiolgenomics.00091.2013 . hal-01019556

\section{HAL Id: hal-01019556 https://hal.science/hal-01019556}

Submitted on 27 May 2020

HAL is a multi-disciplinary open access archive for the deposit and dissemination of scientific research documents, whether they are published or not. The documents may come from teaching and research institutions in France or abroad, or from public or private research centers.
L'archive ouverte pluridisciplinaire HAL, est destinée au dépôt et à la diffusion de documents scientifiques de niveau recherche, publiés ou non, émanant des établissements d'enseignement et de recherche français ou étrangers, des laboratoires publics ou privés. 


\title{
Energy and lipid metabolism gene expression of D18 embryos in dairy cows is related to dam physiological status
}

\author{
D. Valour, ${ }^{1,2}$ S. A. Degrelle, ${ }^{1,2}$ A. A. Ponter, ${ }^{1,2}$ C. Giraud-Delville, ${ }^{1,2}$ E. Campion,,${ }^{1,2}$ C. Guyader-Joly, ${ }^{3}$ \\ C. Richard, ${ }^{4}$ F. Constant, ${ }^{1,2}$ P. Humblot ${ }^{3}$ C. Ponsart, ${ }^{3}$ I. Hue, ${ }^{1,2}$ and B. Grimard ${ }^{1,2}$ \\ ${ }^{1}$ INRA, UMR 1198 Biologie du Développement et Reproduction, Jouy-en-Josas, France; ${ }^{2}$ Université Paris Est, ENVA, UMR \\ 1198 Biologie du Développement et Reproduction, Maisons-Alfort, France; ${ }^{3}$ UNCEIA, Service Recherche et Développement, \\ Maisons-Alfort, France; and ${ }^{4}$ INRA, UE 1298, Unité Commune d'Expérimentation Animale de Bressonvilliers, \\ Leudeville, France
}

Submitted 4 June 2013; accepted in final form 28 October 2013

\begin{abstract}
Valour D, Degrelle SA, Ponter AA, Giraud-Delville C, Campion E, Guyader-Joly C, Richard C, Constant F, Humblot P, Ponsart C, Hue I, Grimard B. Energy and lipid metabolism gene expression of D18 embryos in dairy cows is related to dam physiological status. Physiol Genomics 46: 39-56, 2014. First published November 12, 2013; doi:10.1152/physiolgenomics.00091.2013.-We analyzed the change in gene expression related to dam physiological status in day (D)18 embryos from growing heifers (GH), early lactating cows (ELC), and late lactating cows (LLC). Dam energy metabolism was characterized by measurement of circulating concentrations of insulin, glucose, IGF-1, nonesterified fatty acids, $\beta$-hydroxybutyrate, and urea before embryo flush. The metabolic parameters were related to differential gene expression in the extraembryonic tissues by correlation analysis. Embryo development estimated by measuring the length of the conceptuses and the proportion of expected D18 gastrulating stages was not different between the three groups of females. However, embryo metabolism was greatly affected by dam physiological status when we compared GH with ELC and GH with LLC but to a lesser extent when ELC was compared with LLC. Genes involved in glucose, pyruvate, and acetate utilization were upregulated in GH vs. ELC conceptuses (e.g., SLC2A1, PC, $A C S S 2, A C S S 3)$. This was also true for the pentose pathway ( $P G D$, $T K T)$, which is involved in synthesis of ribose precursors of RNA and DNA. The pathways involved in lipid synthesis were also upregulated in GH vs. ELC. Despite similar morphological development, the molecular characteristics of the heifers' embryos were consistently different from those of the cows. Most of these differences were strongly related to metabolic/hormone patterns before insemination and during conceptus free-life. Many biosynthetic pathways appeared to be more active in heifer embryos than in cow embryos, and consequently they seemed to be healthier, and this may be more conducive to continue development.
\end{abstract}

dairy cow; fertility; energy balance; energy metabolism; conceptus development; gene expression; correlations

IN THE MODERN HOLSTEIN cow, calving rates are close to 55-60\% in heifers and $35-40 \%$ in lactating cows (39, 73). Most pregnancy losses occur prior to the period of maternal recognition and maintenance of the corpus luteum, i.e., before days 15-17 (D15-D17) after artificial insemination (AI), and are due to nonfertilization-early embryonic loss (NF-EEL, Refs. 22, 35, 73). NF-EEL can be estimated in field trials by measuring plasma or milk progesterone concentrations the day of AI and 21-24 days later. The frequency of NF-EEL has been

Address for reprint requests and other correspondence: B. Grimard, Ecole Nationale Vétérinaire d'Alfort, 7, Av. du Général de Gaulle - Bât. Letard 94704 Maisons-Alfort Cedex France (e-mail: bgrimard@ vet-alfort.fr). reported to be between 25 and $45 \%$ in lactating Holstein cows $(26,32,35,52)$, and it has increased from the 1980s (22).

Age/parity, uterine health (nulliparous heifers vs. postpartum cows), and metabolic and endocrine environment are factors that can explain differences in reproductive efficiency. Maternal metabolism is known to influence fertility. Milk production, body condition score (BCS), postpartum BCS variations, negative energy balance (NEB), and quantity and quality of dietary protein supply are related to pregnancy rate (reviews Refs. 15, 40, 45, 65, 73, 76). This effect might be explained partly by the clearance of progesterone in highproducing dairy cows (22) and by poor oocyte quality (43), which impair fertilization ability and early embryonic development. The metabolism of the dam also influences the oviductal and endometrial environment. Early after calving, drastic NEB has an effect on gene expression in the oviduct (24) and the endometrium (74). Mild pre- and postpartum underfeeding alters gene expression in the oviduct and in the endometrium between D4 and D15 postovulation (70). Moreover, recent studies using multiple transfers of in vitro produced embryos report that the ability of the reproductive tract of postpartum lactating cows to sustain embryo development was compromised compared with nulliparous heifers (59) or postpartum nonlactating cows (47) between D2 and D7. The same trend is observed between D7 and D14-D16 when lactating vs. nonlactating cows are compared (7), but not when postpartum lactating vs. postpartum dry cows are compared (47). In these experiments, multiple transfers of in vitro produced embryos were used to avoid confusing effect of dam energy metabolism on oocyte quality ( 3 to 30 by recipient on D7 in Ref. 7, 65 on D2, and 15-20 on D7 by recipient in Ref. 47). Embryo development was evaluated by visual characteristics and/or size (length). However, it was abnormal since it was considerably delayed. This could be due to the high number of embryos/blastocysts transferred to a single recipient $(7,47)$.

Elongation has long been characterized (31) by the transition from a spherical blastocyst [150 $\mu \mathrm{m}$, at 7-8 days postinsemination (dpi)] to a filamentous conceptus $(>20 \mathrm{~cm}$, by $19-20$ dpi). By D14, the conceptus becomes tubular in shape (20 to 50 $\mathrm{mm}$ ). Elongation may also be evaluated by the developmental stage of the embryonic tissues, since both are synchronized when development occurs after AI (20) and thus assessed either by the morphology of the embryonic tissues or gene expression patterns in the embryonic and/or the extraembryonic tissues (EET). Starting from an inner cell mass at the blastocyst stage (7-9 dpi), the embryonic tissues evolve to a germ disc (11-12 dpi) and then to an embryonic disc [14-19 
dpi $(16,72)]$. The genes classically used to follow these stages are Oct-4 or Nodal for pregastrulating stages [D7-D14 (18, 50)] and Brachyury for gastrulating ones [D15-D18 $(20,34)]$. Alternatively an extraembryonic gene set may also be used to define these stages (21).

Extraembryonic gene profiling has not often been performed in the bovine, because of the small number of experiments where the embryonic discs have been dissected out before gene expression analysis. Due to the tiny size of the disc, most investigators consider profiling whole conceptuses to be easier and roughly equivalent. Although molecularly true, dissecting the discs to define the developmental stages of elongating conceptuses provides an advantage: knowing whether the conceptus is fully developed (elongation and gastrulation) or not. So far, molecular studies on bovine elongating conceptuses have identified gene clusters involved in cell growth and differentiation, connective tissue development, lipid metabolism, signaling pathways involving growth factors or cytokines and their receptors, as well as transcription factors $(33,48,68,69)$.

Moreover, gene expression might be used to investigate embryo metabolism and its adaptation to a modification in the oviduct and uterine environment during its free-life. The metabolism of the bovine embryo before D7 has been widely studied with a view to increasing in vitro production efficiency $(42,63,67)$, but little is known of its metabolism before implantation $(30,54)$. In the young embryo, the main energy sources are glucose, lactate, and pyruvate. In the uterus, glucose and amino acids are crucial for embryo development before implantation (6). Betsha et al. (8) used Affymetrix bovine genome array to compare gene expression in D16 elongated bovine embryos from somatic cell nuclear transfer (SCNT) to AI embryos. A considerable reduction in elongation size was observed in SCNT embryos $(93.3 \mathrm{~mm})$ compared with AI embryos (196.3 mm), and this was related to alterations in the expression of genes involved in glycolysis, arginine, proline, pyruvate, and glutathione metabolism (4 pathways among the 11 top canonical pathways affected in SCNT embryos), as seen earlier in D14 and D16 AI embryos (54). Moreover, lipid metabolism is a top function frequently identified by Ingenuity Pathway Analysis (IPA) and cited as differentially expressed between SNCT, in vitro (IVP), and in vivo (IA) produced elongated embryos (33). Lipids and fatty acids are precursors for prostaglandin and steroid hormone biosynthesis. They are included in cell membranes and might be used for energy production in the pathway of $\beta$-oxidation. To our knowledge, the lipid composition of the histotrophs and putative lipid utilization by the peri-implantation bovine embryo has not yet been investigated. Histotroph composition was widely studied in the ewe (6), but there is a major difference between the two species of ruminants: circulating concentrations of fatty acids are high around breeding in the postpartum dairy cow as a consequence of fat mobilization to support milk production but not in the ewe, which is bred after weaning.

In this study, we aimed to investigate the effect of dam physiological status with a special focus on dam energy metabolism prior to $\mathrm{AI}$ and during the beginning of pregnancy on embryo development and conceptus gene expression in single ovulated heifers and postpartum cows. We selected D18 as the point at which to analyze the embryos that survived the embryonic loss occurring before D16, that is to say the em- bryos that within a period of 3 days will face the implantation phase, a crucial period for the success of pregnancy. In doing so, our aim was to: 1) analyze in each group of females which kind of embryos reached the 18th day post-AI, 2) investigate precisely their developmental stage and 3) characterize their alterations in relation to the physiological status of the dam and the potential for further postimplantation embryo development.

\section{MATERIAL AND METHODS}

\section{Animals, Feeding, and Management}

Animals were managed in accordance with the European Community Directive 86-609-EC and under the license of the French Institute of Agricultural Research (INRA-UCEA). The objective was to collect 10 embryos from growing heifers $(\mathrm{GH}), 10$ from early-lactating cows (ELC, collection around D80-D90 postpartum), and 10 from latelactating cows (LLC, collection around D130-D140 postpartum). A total of 67 Holstein animals were included in the protocol: 19 heifers $[14.3 \pm 0.4$ (mean \pm SE) mo old, $351.6 \pm 8.6 \mathrm{~kg}$ of body weight (BW), $2.1 \pm 0.1$ points of BCS (scale from $0=$ very thin to $5=$ very fat)] and 48 multiparous cows (rank of lactation $3.2 \pm 0.2$, range from 2 to $8 ; 683.5 \pm 11.2 \mathrm{~kg} \mathrm{BW}$ at calving, $3.2 \pm 0.1$ points of BCS at calving). In the cows, the proportions of unassisted calving, easy calving and hard pull at calving were $31 / 48(65 \%), 16 / 48(33 \%)$, and $1 / 48(2 \%)$.

Heifers received a diet composed of natural prairie hay $(7 \mathrm{~kg} / \mathrm{day} /$ animal), mineral and vitamin complements (140 g/day/animal), liquid nutritional supplement (20 g once a week), and concentrate $(1 \mathrm{~kg}$ / day). The diet was designed to allow a daily weight gain of $600 \mathrm{~g} /$ day (36). After a 4 wk period of adaptation, they were monitored over 10 wk. They were submitted to an estrus induction and synchronization treatment in week 6 and were inseminated in week 8, and embryos were collected 18 days after insemination in week 10 .

After calving, cows received ad libitum a total mixed ration (maize silage, natural prairie hay, commercial concentrates, minerals, and vitamins) designed to cover requirements for a milk production level of $37 \mathrm{~kg}$ /day (36). They were first estrus-synchronized to be inseminated between D60 and D70 postpartum, and embryos were collected 18 days later (between D80 and D90, ELC). Nonpregnant cows after the first insemination were resubmitted to an estrus synchronization treatment and inseminated between D110 and D120 postpartum and collected 18 days later between D130 and D140 (LLC). BW and BCS were evaluated every $2 \mathrm{wk}$. Milk production, milk fat, and protein content were measured once a month in cows.

\section{Blood Sampling, Hormone and Metabolite Assays}

Blood samples were collected weekly by caudal venipuncture before the morning feed. Blood was immediately centrifuged at 2,000 $\mathrm{g}$ for 15 $\min$ at $4{ }^{\circ} \mathrm{C}$ to harvest plasma, which was stored at $-20^{\circ} \mathrm{C}$ until required for analysis. Plasma samples were analyzed by photometric methods for glucose (Glucose-RTU; BioMérieux, Lyon, France), nonesterified fatty acids (NEFA C; Wako Chemicals, Neuss, Germany), urea (Urea-kit S, BioMérieux), $\beta$-hydroxybutyrate (BHB, method adapted from Ref. 3). Insulin and IGF-1 were analyzed by radioimmunoassays based on, respectively, porcine insulin (Insulin-CT; CIS Bio International, Gif-surYvette, France) and human recombinant IGF-1 (IGF-I-RIACT, CIS Bio International). IGF-BPs were removed following the manufacturer's instructions. Plasma progesterone (P4) concentrations were measured with an ELISA kit prepared for bovine serum or plasma (OVUCHECK PLASMA; Biovet, St-Hyacinthe, Canada). Interassay coefficients of variation were 11.2, 9.3, 8.3, 11.3, 12, 9.6, and $10.8 \%$ for glucose, NEFA, urea, BHB, insulin, IGF-1, and P4. Intra-assay coefficients of variation were 11.2, 12.4, 11.3, 8.3, 11.7, 6.0, and 6.3\% for glucose, NEFA, urea, BHB, insulin, IGF-1, and P4. 


\section{Reproductive Management and Estrus Synchronization Treatment}

In the cows, uterine involution was checked on D30 postpartum by transrectal palpation, ultrasonography, and vaginoscopy. When abnormal uterine involution was diagnosed (vaginal discharge, uterine horn diameter $>5 \mathrm{~cm}$, cervix diameter $>7.5 \mathrm{~cm}$ ) im injection of prostaglandin analog (500 $\mu \mathrm{g}$ Cloprostenol, $2 \mathrm{ml}$ Estrumate; MSD Santé Animale, Beaucouzé, France) and an intrauterine antibiotic 2 days later (500 mg Cephapirin, Metrijet; MSD Santé Animale) were performed. The estrus synchronization treatment combined a $3 \mathrm{mg}$ Norgestomet ear implant for 9 days (Crestar, MSD Santé Animale), an im injection of $10 \mu \mathrm{g}$ Busereline (2.5 ml Receptal, MSD Santé Animale) at implant insertion, and $500 \mu \mathrm{g}$ Cloprostenol (2 $\mathrm{ml}$ Estrumate, MSD Santé Animale) $48 \mathrm{~h}$ before implant removal. In cows, 400 UI of equine chorionic gonadotropin (eCG) (Chronogest PMSG, MSD Santé Animale) were injected im at implant removal. As recommended by the laboratory, eCG was not used in heifers to prevent multiple ovulations. The females were inseminated $48 \mathrm{~h}$ after implant removal.

\section{D18 Embryo Flush}

At 18 dpi, conceptuses were collected with a modified catheter (IMV Technologies, L'Aigle, France) to flush the uterus with warm PBS. After flushing, each recovered conceptus was carefully rinsed in fresh PBS before treatment. For each conceptus $(n=32)$, the embryonic disc was dissected out when visible and stored separately from the EET. Embryonic discs were fixed in formaldehyde, and EET were snap-frozen in liquid nitrogen before storage at $-80^{\circ} \mathrm{C}$ until RNA extraction.

\section{Embryo Sexing}

Genomic DNA was obtained from each conceptus after total RNA extraction from EET using Trizol (as per the manufacturer's instructions). The sex of the embryos was genetically determined by PCR with primers R-IV/U-IV and BTANRP1/2 as described by Alves et al. (1): R-RIV 5'-GTT TTA TTA TCC CAG CAAG-3', U-IV 5'-TAT TCC TTT GGG GAG CA-3', BTANRP1 5'-CCA ACT TTC CCT TCT TTC CC-3', and BTANRP2 5'-ATG GCC CAA AAG AAC ATT CA-3'. Briefly, primers R-RIV/U-IV amplified a 655 bp Yspecific sequence present in male genomic DNA and primers BTANRP1/2 amplified a $370 \mathrm{bp}$ BTANRP sequence present in all tested samples, thus showing the effectiveness of the PCR reactions. DNA was amplified using an initial denaturizing step at $94^{\circ} \mathrm{C}$ for 5 min, followed by 35 cycles of denaturation at $94^{\circ} \mathrm{C}$ for $45 \mathrm{~s}$, annealing at $55^{\circ} \mathrm{C}$ for $45 \mathrm{~s}$, and synthesis at $72^{\circ} \mathrm{C}$ for $45 \mathrm{~s}$. An extension time of 5 min was added at the end of the final cycle.

\section{Embryonic Stage Determination}

A total of 23 embryonic discs were available: 9, 7, and 7 in $\mathrm{GH}$, ELC, and LLC, respectively. The isolated embryonic discs were fixed in $4 \%$ paraformaldehyde, stored, and hybridized with a BrachyuryDIG-labeled riboprobe as described by Hue et al. (34). When no disc was available $(n=6)$, the developmental stage of the embryonic disc was determined by PCR using a set of six extraembryonic genes that previously proved to be accurately predictive: $C A L M 1, C P A 3$, CITED1, DLD, HNRNPDL, and TGFB3. In both cases, the embryo staging was performed as described by Degrelle et al. (21).

\section{RNA Isolation and Amplification}

Eight EET were RNA-extracted in GH, 11 EET in ELC, and 10 in LLC (total for molecular analysis $n=29$ ). Total RNA from EET was isolated with Trizol (Life Technologies - Invitrogen, St-Aubin, France), and linear amplification was performed with the MessageAmp aRNA kit (Ambion, Courtaboeuf, France), starting from $1 \mu \mathrm{g}$ total RNA as described by Degrelle et al. (19). The same process was applied to a pool of placental tissues that was used as a reference later in the experimental design for array hybridization.

\section{Microarrays}

Microarrays used in this study were $22 \mathrm{~K}$ bovine oligonucleotide probe arrays [National Center for Biotechnology Information (NCBI) Gene Expression Omnibus (GEO): 6695] spotted by Centre de Ressources Biologiques - Génomique des Animaux Domestiques et d'Intérêt Economique (CRB-GADIE; INRA, Jouy-en-Josas, France). Of the 23,232 probes spotted on the slides, 960 were empty spots, 260 were spots containing buffer, 8,709 spots were oligonucleotides from the Bovine Genome Oligoset V1.1 (Operon Biotechnologies), and 13303 spots were oligonucleotides from a pre-existing set (NCBI GEO: GPL2853), developed from a bovine embryo cDNA library. These two bovine oligonucleotide sets were identified as "Operon" and "Illumina" sets, respectively, and annotated by Sigenae, INRA, France (Système d'Information des GENomes des Animaux d'Elevage, http://www.sigenae.org). The annotation of the array was updated in May 2013.

\section{Probe Labeling, Array Hybridization}

Amplified RNA was labeled with the ULS aRNA Labeling Kit (Kreatech Diagnostics, Amsterdam, The Netherlands). Briefly, $2 \mu \mathrm{g}$ of amplified RNA were directly labeled with $2 \mu \mathrm{l}$ of Cy(3-5)-ULS. Amplified RNA and Cy-ULS were mixed with $2 \mu \mathrm{l}$ of $10 \times$ labeling solution to obtain a $1 \times$ labeling solution mixture in a volume of $20 \mu \mathrm{l}$ (adjusted with ultrapure water). The mixture was incubated at $85^{\circ} \mathrm{C}$ for $15 \mathrm{~min}$ and chilled on ice. Labeled targets were then purified on KREApure columns.

Frequencies of dye incorporation (FOI, rate per thousand labeled nucleotides) and cDNA concentrations were estimated for both dyes by measuring the absorbance at 260,550 , and $650 \mathrm{~nm}$ on a Nanodrop spectrophotometer (Thermo Scientific). The following ratios were calculated: FOI per 1,000 bases $(\mathrm{Cy} 3)=58.5 *$ Abs550/Abs260, FOI per 1,000 bases $(\mathrm{Cy} 5)=35.1 *$ Abs650/Abs 260 .

Prior to hybridization, microarrays were prehybridized for $30 \mathrm{~min}$ at $50^{\circ} \mathrm{C}$ in a filtered solution of $1 \% \mathrm{BSA}, 3.5 \times \mathrm{SSC}$, and $0.1 \% \mathrm{SDS}$ and rinsed twice at room temperature in ultrapure water for 5 min with orbital agitation. They were dried by compressed air.

A reference design was developed for array hybridization (37). In this design, each experimental sample of EET was hybridized against a reference that hybridized to $95.8 \%$ of the probes and was a pool of placental tissues. To minimize the variance associated with labeling, the amplified aRNA from the pool of placental tissues were always labeled with $\mathrm{Cy} 3$, while EET from the different conceptuses were always labeled with Cy5. Thus, all the slides were hybridized with the same placental reference, while each slide corresponds to one specific EET.

The hybridizations were processed on the ICE platform (previously PICT-Gem, http://www4.jouy.inra.fr/gabi_eng/Our-resources/ICEIntegrated-Microgenomics-platform) of Jouy-en-Josas, France. Each microarray was cohybridized with two fluorescently labeled (Cy3 and Cy5) aRNA samples according to the experimental design. An evaluated amount of $500 \mathrm{ng}$ of each labeled aRNA was fragmented for 30 $\min$ at $60^{\circ} \mathrm{C}$ in $1 \times$ fragmentation buffer (Agilent Technologies). KREAblock is a background blocker and was added as $1 / 4$ of the final volume of $200 \mu \mathrm{l}$ (adjusted with ultrapure water).

Then fragmented labeled aRNA samples were diluted in $200 \mu \mathrm{l}$ of Agilent hybridization buffer $2 \times$ and hybridized on the $22 \mathrm{~K}$ bovine oligo-array for $20 \mathrm{~h}$ at $60^{\circ} \mathrm{C}$ in a rotating hybridization oven (Agilent Technologies).

After hybridization, microarrays were washed at room temperature with orbital agitation successively twice for $5 \mathrm{~min}$ in a $2 \times \mathrm{SSC}-0.1 \%$ SDS solution, once for $5 \mathrm{~min}$ in a $0.5 \times \mathrm{SSC}-0.1 \%$ SDS solution, and three times for $5 \mathrm{~min}$ in a $0.2 \times \mathrm{SSC}$ solution. They were finally dried with compressed air. 


\section{Image Acquisition and Quantification}

Microarrays were scanned on an Agilent scanner (Agilent Technologies, G2505B Microarray Scanner System) at a $10 \times 10 \mu \mathrm{m}$ pixel resolution provided by the CRB-GADIE. Feature extraction was performed with GenePix Pro 6.1.0.4 software to quantify mean and median signals for each sample and for background estimation. Extracted data were stored in the BioArray Software Environment (BASE) of SIGENAE and then formatted according to MIAME standards (11). The data have been submitted to the NCBI GEO database and are referenced as series GSE46940.

\section{Validation of Gene Expression Data by RT-PCR}

The purified aRNA samples analyzed by microarray hybridizations were used for the quantitative RT-PCR (RT-qPCR). Primers (Table 1) were designed based on the target sequences of the array (close to $3^{\prime}$-untranslated region) with the primer designing tool Primer-BLAST (NCBI, http://www.ncbi.nlm.nih.gov/tools/primer-blast/) to specifically amplify 16 selected genes and five housekeeping genes in the EET of GH, ELC, and LLC.

For the selected EET ( $n=15,5$ by group of dam; all fully elongated with properly gastrulated embryonic disc), cDNA were synthesized twice (then pooled) from $1 \mu \mathrm{g}$ of aRNA by reverse transcription using Superscript II as reverse transcriptase and random hexamers as primers. A pool of all the cDNA was successively diluted and used to generate standard curves in qPCR to estimate the efficiency (E) and the specificity of primers. The amplified fragments were sequenced and then BLASTed to confirm that the correct gene was amplified.

The RT-qPCR were performed with the SYBR Green PCR Master Mix and the StepOnePlus Real-Time PCR Systems (Applied Biosystems by Life Technologies, St-Aubin, France).

According to the delta-CT method [RQNorm sample $_{\text {e }}=$

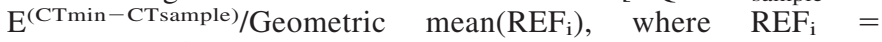
$\left.\mathrm{E}^{\text {(CTmin-CTref) }}\right]$ described in the geNorm method (71), the relative quantification of aRNA of the selected differentially expressed genes (DEG) (RQNorm) was calculated against RPL19, RPS18, GAPDH,
$A C T B$, and B4GALT5 as previously used in Ref. 70. Reference genes for normalization were all selected for stability by the geNorm method.

\section{Data Analysis}

Energy balance (EB) was evaluated for cows monthly (3 time points) before and at conceptus flush as the difference between energy requirements (maintenance + milk production) and energy supply (energy provided by the diet, which was considered to be ingested to fill voluntary feed intake). Milk production was recorded by the milk production board, and voluntary feed intake was calculated to take into account: age in months, parity, BW, BCS, milk production, and milk fat (36). EB was expressed in the French net energy system for lactation (unité fourragère lait, $1 \mathrm{UFL}=$ net energy provided by $1 \mathrm{~kg}$ of barley, 1.7 Mcal of net energy) per day.

Repeated BW, BCS, milk production, plasma concentrations of metabolites and hormones, and estimated EB were compared between GH, ELC, and LLC by split-plot ANOVA with the MIXED procedure of the SAS Software (SAS Inst., Cary, NC), including the fixed effects: group of dam, time, and group $\times$ time, and the random animal effect. Results are presented as least-square means $\pm \mathrm{SE}$.

P4 concentrations in blood measured each week between AI and D18 as well as conceptuses' lengths were compared by $t$-tests. A linear regression was performed between the plasma P4 of females at D18 of pregnancy and the length of the conceptuses. The correlation of those data was evaluated by the coefficient of determination $\left(r^{2}\right)$ of the linear regression.

Microarray data were analyzed with R Program Writer software (http://www.r-project.org/) (57). Median signal normalization was performed using the "limma" $\mathrm{R}$ package based on "normalizeWithinArrays" (log2-transformation, median centering and global loess) and "normalizeBetweenArrays" (Aquantile transformation) procedures. Probes with intensity below the background were flagged absent and were not entered in the analysis.

A two-dimensional principal component analysis (PCA) was performed with the package "ade4" (23) to test the effect of the group of

Table 1. Primer sequences per international (5'-3') convention for selected DEG and housekeeping genes (ACTB, B4GALT5, GAPDH, RPL19, RPS18) analyzed by RT-qPCR

\begin{tabular}{|c|c|c|c|c|c|}
\hline Gene & Fw Primer & Size Fw, bp & Rev Primer & Size Rev, bp & Size Amplicon, bp \\
\hline$A B C G 2$ & ATCTCAAAACCGTCGTGCCT & 20 & TCATTATGCTGCAAAGCCGC & 20 & 85 \\
\hline$A P O E$ & TTCTGGGATTACCTGCGCTG & 20 & TCACCTCCTTCATGGTCTCCTC & 22 & 118 \\
\hline ATP6V1D & CTGGTTTAGCCAGAGGTGGG & 20 & AGTGAAGCCAGTTCCACCAG & 20 & 88 \\
\hline$C T G F$ & AGACCTGTGCCTGCCATTAC & 20 & GGCTTTAGGCCATGTCTCCA & 20 & 93 \\
\hline$D B I$ & CTCTTGTGCTGCTGCTACCT & 20 & CTCATCTGCTGGCTTGGTCT & 20 & 139 \\
\hline ELF3 & TAAGCACGGGAAGCGGAAAA & 20 & GGTGGATGAGGATGTCACGG & 20 & 137 \\
\hline IGFBP4 & TGGTTCACTGTCTGTGGCTC & 20 & AAAAATGCCCAGGGGTAGGG & 20 & 88 \\
\hline LIPA & GCAGGCCATAAAGCCACTTG & 20 & TCTACACATGCCATCGCCAG & 20 & 121 \\
\hline NDUFA1 & TCCACAGGTTCAGTAACGGC & 20 & GACGCGCCTATCTCTTTCCA & 20 & 86 \\
\hline NDUFC2 & GTATGCTGTGAGGGACCACG & 20 & ACTTCAACGCACTGGATGGA & 20 & 121 \\
\hline NDUFS6 & GGGAGTCGGGTGATATCGTG & 20 & GTCCCCGTCTTCGTTTCCTT & 20 & 92 \\
\hline$P C$ & CCCTGGACAGCCTCAATACG & 20 & CGAAGAAGACCTGCCTCTGG & 20 & 150 \\
\hline$P G F$ & CTGCTTGTGCTGGGACATTG & 20 & GGCCCACTTTTTGCCTTTGT & 20 & 81 \\
\hline RBP4 & TCTTTCGTGTTTGCCCGAGA & 20 & AACCGTTGTGAGGGATCAGC & 20 & 118 \\
\hline SLC2A1 & GAGAGGGGAAGGGCCATACT & 20 & GCAGGAGTGTCCAGGTCTTC & 20 & 132 \\
\hline STARD10 & ATCCAGACGGGCTACCTCAT & 20 & GGGAGCCAGGAACTGAGAAG & 20 & 129 \\
\hline \multicolumn{6}{|c|}{ Housekeeping genes } \\
\hline$A C T B$ & GCTTTACCACCACAGCCGAGCG & 22 & CGACGCAGCAGTAGCCATCT & 20 & 100 \\
\hline B4GALT5 & GAGGAAGTCCAAGGAGCGG & 19 & TCGGGTGTCAAGTTGACGGT & 20 & 111 \\
\hline$G A P D H$ & GCCGATGCCCCCATGTTTGT & 20 & TCATAAGTCCCTCCACGATGC & 21 & 151 \\
\hline RPL19 & CCCCAATGAGACCAATGAAATC & 22 & CAGCCCATCTTTGATCAGCTT & 21 & 73 \\
\hline RPS18 & CGGAAAATTGCCTTTGCCAT & 20 & CCTCATCCTCGGTGAGCTCC & 20 & 121 \\
\hline
\end{tabular}

Optimal annealing temperature: $60^{\circ} \mathrm{C}$. Most primers were specifically designed for this study except for $A P O E$ (M. Raliou, UMR BDR 1198 , unpublished data) and ACTB, B4GALT5, GAPDH, RPL19, RPS18 (70). DEG, differentially expressed gene; Fw, forward; Rev, reverse. 
dam (GH, ELC, LLC), the length and sex of the conceptuses, and the developmental stage of the embryonic disc on global gene expression in the EET of the conceptuses.

A differential analysis was designed to test the effect of dam group (GH, ELC, or LLC) on gene expression in the EET. Normalized data entered a linear model by the 'Imfit' procedure and were tested by an empirical Bayes statistics for differential expression ("ebayes"). Raw $P$ values were adjusted for multiple testing with a Benjamini-Hochberg correction to control the false discovery rate (FDR).

DEG were investigated under a 5\% significance threshold (FDR < $0.05)$. Functions of the DEG were analyzed with NCBI web tools and IPA (Ingenuity Systems, http://www.ingenuity.com).

A hierarchical clustering (PermutMatrix, Ref. 14), using Pearson's distance, was performed on differentially expressed genes to visualize the similarity between individuals.

To assess differential expression, $t$-tests were performed on the results obtained from RT-qPCR. Input data were the means of duplicates of RT-qPCR values.

DEG were then analyzed for correlations with patterns of metabolites/hormones by two-dimensional regularized canonical correlation analysis (RCCA). To correlate gene expression in the conceptuses to temporal metabolite/hormone measurements, parameters representative of metabolism variations before embryo flush in the three groups of dam were computed as previously proposed by Valour et al. (70).

Thus, to process RCCA, we calculated regularization parameters on the basis of the functions provided in the R package CCA (28). RCCA were investigated according to the three principal components (fall of eigenvalues). Metabolite-gene interactions were quantified with the correlation between the two types of projected variables onto the space spanned by the first components retained in the RCCA (package "mixOmics" in R, Ref. 38). IPA was finally used to highlight the biological functions and networks of the DEG selected by RCCA.

\section{RESULTS}

D18 conceptuses were recovered from $11 \mathrm{GH}, 11 \mathrm{ELC}$, and 10 LLC. The interval between calving and AI was $63 \pm 1$ days for ELC and $117 \pm 1$ days for LLC, and GH were inseminated at $17.1 \pm 0.3$ mo old. The interval between calving and conceptus collection was $81 \pm 1$ days in ELC, $135 \pm 1$ days in LLC.

Among the 48 cows, five were diagnosed with delayed uterine involution and were treated. Among them, three were pregnant at first service and one at the second service. Four needed easy pulls at calving in the two groups of pregnant cows (4/11 in ELC, 4/10 in LLC), and the others were unassisted.

\section{$B W, B C S$, and Performance of Pregnant Females}

The characteristics of pregnant cows are presented in Table 2 and Fig. 1. During the 12 wk preceding AI and conceptus

Table 2. Characteristics of pregnant lactating cows

\begin{tabular}{lcc}
\hline \multicolumn{1}{c}{ Characteristics } & ELC $(n=11)$ & LLC $(n=10)$ \\
\hline Rank of lactation & $3.5 \pm 0.6$ & $2.9 \pm 0.3$ \\
Milk genetic merit, kg/yr relative to & & \\
$\quad$ the mean of the breed & $228.5 \pm 130.8^{\mathrm{a}}$ & $585.9 \pm 99.8^{\mathrm{b}}$ \\
Peak milk production, kg & $38.9 \pm 3.3$ & $39.1 \pm 0.6$ \\
BW at calving, kg & $687.3 \pm 26.7$ & $654.1 \pm 27.7$ \\
BCS at calving, points & $3.2 \pm 0.1$ & $3.1 \pm 0.2$ \\
BW at embryo flush, kg & $644.1 \pm 36.5$ & $647.6 \pm 19.9$ \\
BCS at embryo flush, points & $1.7 \pm 0.3$ & $1.5 \pm 0.2$ \\
Milk production at embryo flush, $\mathrm{kg}$ & $34.1 \pm 2.3$ & $34.6 \pm 1.1$ \\
\hline
\end{tabular}

a vs. b, Significant differences with $P<0.05$. BW, body weight; BCS, body condition score. ELC, early lactating cow; LLC, late lactating cow. collection, heifers and LLC were gaining weight, while ELC were losing weight. During this period, BCS was decreasing in ELC, increasing in GH, and remaining stable in LLC. Daily weight gain was, respectively, $517 \pm 24,-392 \pm 143$, and $48 \pm 74 \mathrm{~g}$ per day in GH, ELC, and LLC during the $12 \mathrm{wk}$ before conceptus recovery. Milk production was lower in LLC 1 mo before conceptus collection compared with ELC. At conceptus collection, GH were gaining weight; EB was slightly positive in LLC and still negative in ELC. BW and BCS at calving, mean lactation rank, and peak milk production were not different between the two groups of lactating cows. Genetic merit for milk production was significantly lower in ELC compared with LLC $(P<0.05)$.

\section{Blood Metabolites and Hormones 9 wk Before Conceptus Flush at D18}

Kinetics of metabolites and hormones during the 9 wk before conceptus recovering are presented on Fig. 2 .

Plasma glucose concentrations were higher in heifers than in cows but were not different between the two groups of cows except in weeks -9 and 0 .

Plasma NEFA concentrations were low and close to/or inferior than $0.2 \mathrm{mmol} / \mathrm{l}$ throughout the period of observation in heifers. They were lower in GH than in ELC throughout the experiment and lower in GH than in LLC between weeks -9 and -6 . Plasma NEFA concentrations were higher in ELC than in LLC from week -9 to week -1 .

Plasma BHB concentrations were lower in GH than in ELC between weeks -9 and -4 but were not different from LLC. They were higher in ELC than in LLC between weeks -9 and -5 .

Plasma urea concentrations were lower in heifers than in cows. They were lower in ELC cows than in LLC cows in weeks -9 and -4 .

Plasma IGF-1 concentrations were 10-fold higher in heifers than in cows throughout the period of observation, but they were not different between the two groups of cows.

Plasma insulin concentrations were higher in heifers than in ELC except in week -4 , and they were higher in GH than in LLC in weeks $-6,-5,-3,-2$. They were lower in ELC than in LLC in weeks -8 and 0.

During the 3 last weeks of the period of observation (period when the D18 conceptuses are free-living) the metabolic status was more favorable in GH than in ELC (higher glucose, IGF-1, and insulin in weeks -2 and 0 and lower NEFA and urea). Some significant differences were observed between $\mathrm{GH}$ and LLC (higher glucose in week 0 , IGF-1 and insulin on weeks -2 and 0 , and lower urea in weeks -2 and 0 ) and between ELC and LLC (lower glucose in week -1, higher NEFA in weeks -3 and -2 and lower insulin in week 0 ).

\section{P4 Profiles From AI to D18 of Pregnancy}

After synchronization, the levels of P4 in blood were not different between the three groups of females $(P>0.05)$. They were $7.27 \pm 0.33 \mathrm{ng} / \mathrm{ml}$ at D7 and $8.6 \pm 0.36 \mathrm{ng} / \mathrm{ml}$ at D18.

\section{Recovered Conceptuses and Elongation}

The recovery rates and the size of the conceptuses at D18 of pregnancy are presented in Table 3 . We collected 11 conceptuses from 19 heifers (conceptus recovery rate: $58 \%$ ), while three other conceptuses were suspected of having early embryonic loss 
Fig. 1. Physiological status of the dams. Body weight (BW), body condition score (BCS), milk production (MP), and energy balance (EB) before conceptus collection at day (D) 18 after artificial insemination (AI) in growing heifers $(\mathrm{GH}, n=11)$, early lactating cows (ELC, $n=11$ ), and late lactating cows (LLC, $n=10) . * * * * P<0.0001, * * * P<0.001$, $* * P<0.01, * P<0.05$. The numbers close to the significance symbols indicate which group(s) is (are) significantly different from the value annotated.
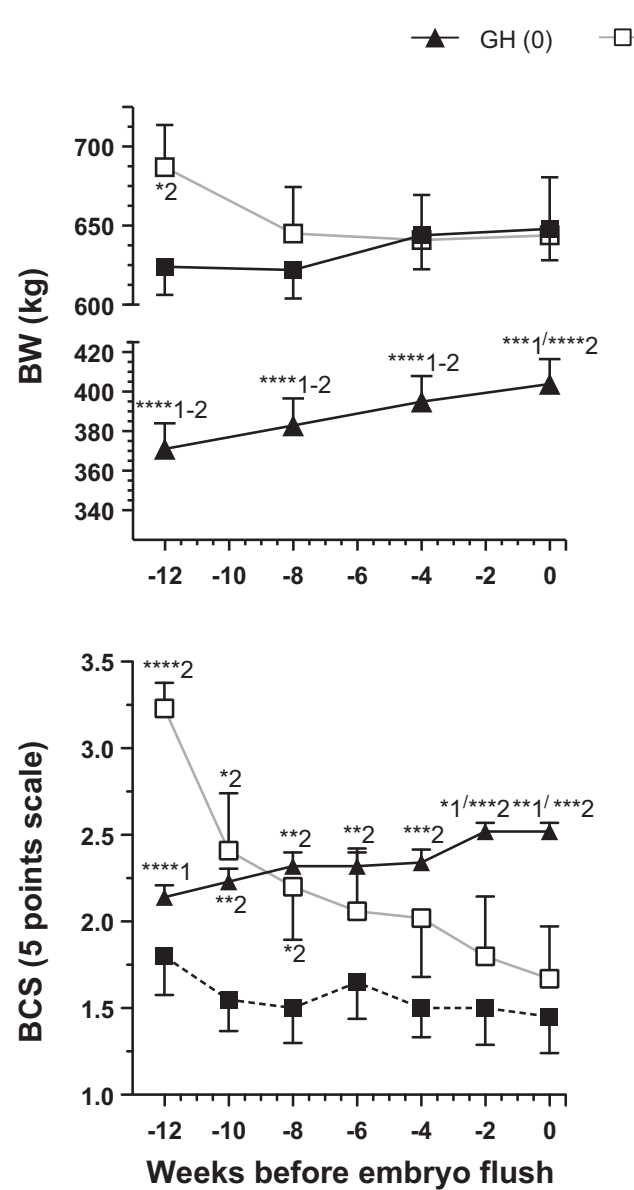
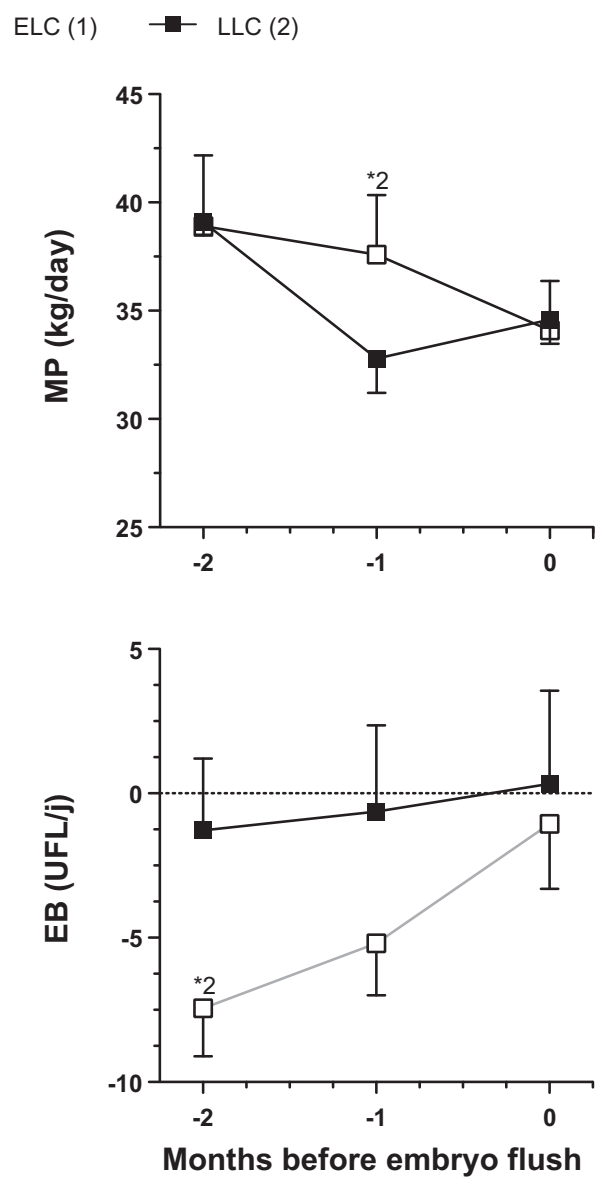

(collection of trophoblastic vesicles). Among the 48 multiparous cows, 11 gave a D18 conceptus after the first insemination (conceptus recovery rate: $23 \%$ ). Among the nonpregnant cows after the first AI, 35 were resubmitted to estrus synchronization and AI. Of those, we collected 10 conceptuses (conceptus recovery rate: $29 \%$ ). The recovery rate of the heifers was significantly higher than the recovery rate of the two groups of cows $(P<$ $0.05)$, but the recovery rates of the two groups of cows were similar.

The elongation status of the D18 conceptuses was homogeneous within the three groups of females $(P>0.05)$ since mainly filamentous $(>15 \mathrm{~cm})$, early filamentous $(10-15 \mathrm{~cm})$, and tubular $(3-10 \mathrm{~cm})$ conceptuses were collected, with only two that were atypically small $(1.5 \mathrm{~cm})$ and resembled D12 rather than D18 conceptuses. These two conceptuses originated from the GH and LLC groups. The correlation between the level of circulating P4 and the length of the conceptuses at D18 was nonsignificant ( $\left.r^{2}=0.38, n=32, P>0.05\right)$.

Sex ratios were not different between groups as the conceptuses collected in GH, ELC, and LLC were, respectively, composed of 5 vs. 3,5 vs. 6 , and 7 vs. 3 males vs. females.

The morphological and molecular staging of the embryonic discs $(n=23)$ revealed similar proportions of the expected D18 gastrulating stages in the three groups of females $(5 / 9$ in $\mathrm{GH}, 4 / 7$ in ELC, and 3/7 in LLC), i.e., stages that display an early or a late primitive streak as described in Degrelle et al. (21). In each group, however, few embryonic discs appeared younger than expected at D18, since a posterior pole instead of a streak was visualized by the Brachyury labeling (Table 4). As for the elongation status, only two atypical stages were observed at the gastrulation level: one in the ELC and one in the LLC group. Similarly, the prediction of the embryonic stages in the conceptuses where no disc was found at the time of collection also revealed a majority of expected D18 stages $(3 / 4)$, i.e., late streak (or stage $4, n=2$ ) and early streak (or stage $3, n=1$ ). One younger disc (posterior pole but no streak, stage 2) was also found (in the LLC group), and two remained undetermined (one in the GH group of dam, one in the LLC one). Altogether, 24/27 had properly gastrulated at D18, 18 being at the expected stages ( 3 or 4 ) and six slightly delayed (stage 2).

\section{Dam Physiological Status and Gene Expression in D18 EET}

The gene expression profiles were evaluated individually in the 29 EET, according to the reference design. A two-dimensional PCA of the genes expressed within these EET revealed that the sex of the conceptus, the development stage of the disc (D18 vs. earlier than D18), or the elongation degree of the EET (filamentous vs. tubular) explained $3.1,1.4$, and $5.1 \%$ of the variability, respectively. Conversely, the physiological status of the dams represented $23.7 \%$ of the variability observed in the overall gene expression pattern (Fig. 3). In the present work, the repeated spotted probes and the probes targeting the same gene were not averaged but checked for similar expression. In doing this, we first identified 483 differentially ex- 


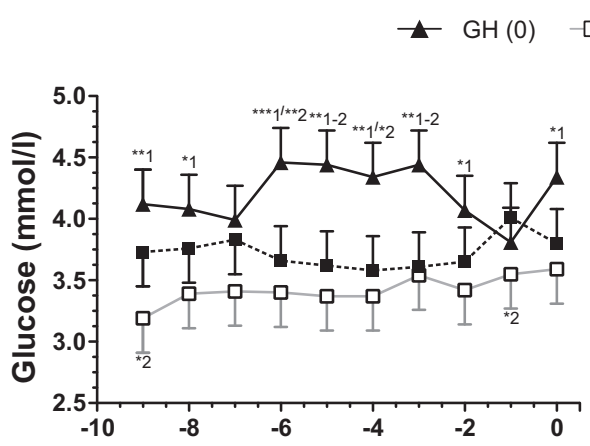

ELC (1) --7- $\operatorname{LLC}(2)$
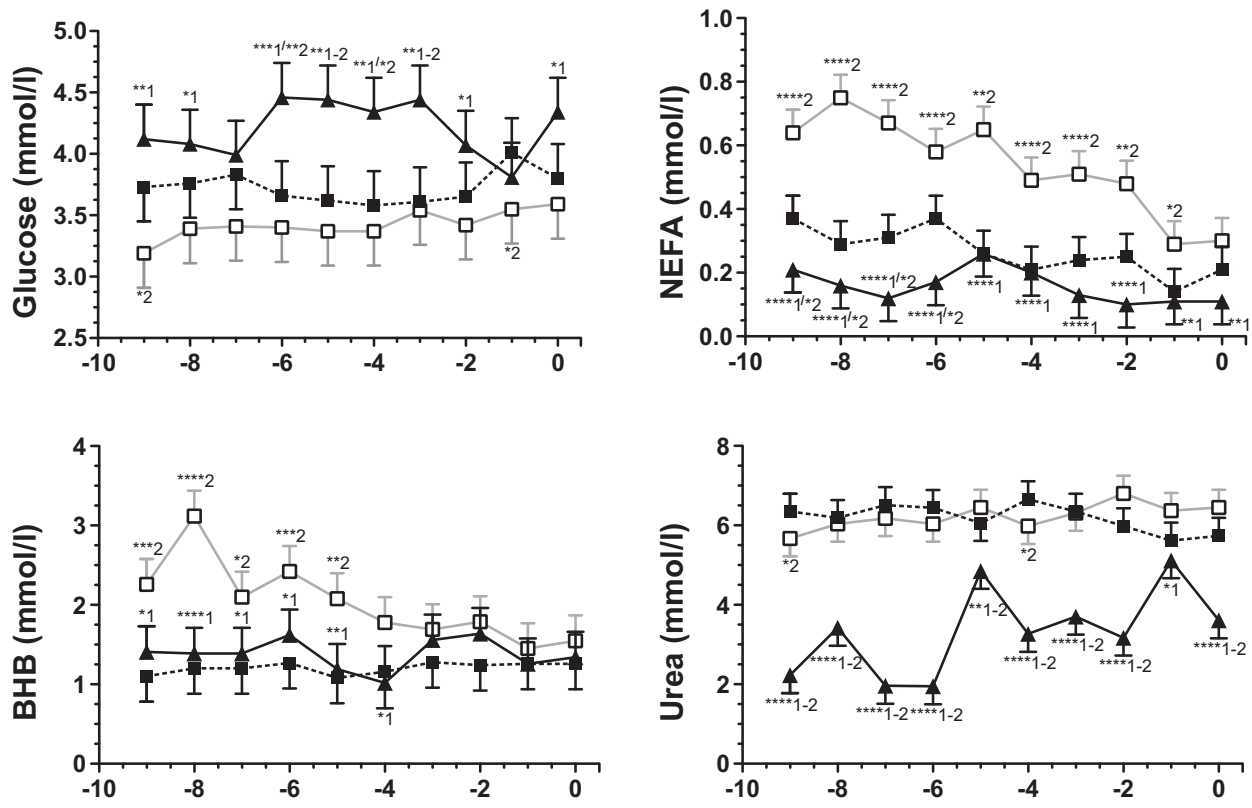

Fig. 2. Metabolic status of the dams. Plasma concentrations of metabolites and hormones before conceptus collection at D18 post-AI in $\mathrm{GH}(n=11), \mathrm{ELC}(n=11)$, and LLC $(n=$ 10). $* * * * P<0.0001, * * * P<0.001, * * P<$ $0.01, * P<0.05$. The number close to the significance symbols indicate which group(s) is (are) significantly different from the value annotated. NEFA, nonesterified fatty acids; BHB, $\beta$-hydroxybutyrate; IGF-1, insulin-like growth factor-1.

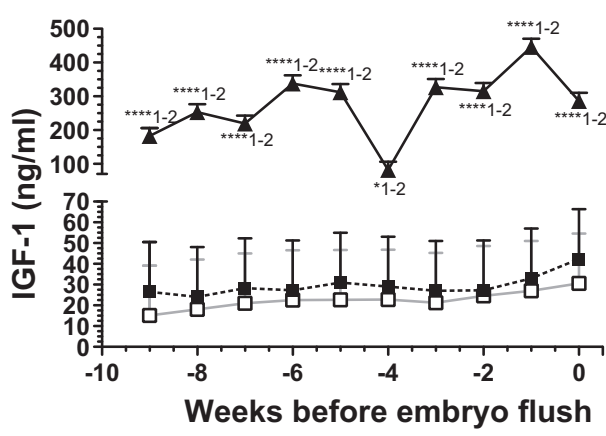

pressed probes between the D18 EET of GH and ELC (362 $\uparrow$ in $\mathrm{GH}, 121 \uparrow$ in ELC) among which 333 were annotated and unique (247 $\uparrow$ in GH, 86 $\uparrow$ in ELC, Fig. 4). We found 459 probes to be differentially expressed between the D18 EET from GH and LLC (247 $\uparrow$ in GH, $212 \uparrow$ in LLC), among which 357 were annotated and unique (198 $\uparrow$ in GH, 159 $\uparrow$ in LLC). Finally, 105 probes were differentially expressed between the D18 EET collected from ELC vs. LLC (68 $\uparrow$ in ELC, $37 \uparrow$ in LLC), among which 75 were annotated and unique $(52 \uparrow$ in ELC, $23 \uparrow$ in LLC). EET developed in lactating cows were thus molecularly less different than those developed in heifers, whereas the most different D18 EET were those from GH vs. ELC. Moreover, most of the differential expressions observed in this work appeared as higher expressions in the D18 EET that developed in heifers (301/434, Fig. 4).

Within the annotated and unique probe set, the gene expression differences observed between the EET from heifers or lactating cows were only partly similar with 73 common genes out of 493 (Fig. 4). Even less were common when comparing $\mathrm{GH}$ vs. LLC and ELC vs. LLC $(n=15)$ or GH vs. ELC and ELC vs. LLC $(n=11)$, and very few were common to the three

Table 3. Conceptus recovery rate and conceptus size at D18 after AI, in GH, ELC, and LLC

\begin{tabular}{|c|c|c|c|c|c|c|}
\hline & & \multirow[b]{2}{*}{$\begin{array}{c}\text { Recovery Rate, Conceptus, } \\
n(\%)\end{array}$} & \multicolumn{4}{|c|}{ Elongated D18 Conceptuses } \\
\hline Group & Females, $n$ & & $\begin{array}{l}\text { Filamentous and Early } \\
\text { Fil., } n(\%)\end{array}$ & Length $(\mathrm{mm})$, mean $\pm \mathrm{SD}$ & $\begin{array}{c}\text { Tubular and Ovoid, } \\
n(\%)\end{array}$ & Length $(\mathrm{mm})$, mean $\pm \mathrm{SD}$ \\
\hline GH & 19 & $11(57.9)$ & $7(63.6)$ & $151.4 \pm 10.9$ & $4(36.4)$ & $58.3 \pm 21.6$ \\
\hline ELC & 48 & $11(22.9)$ & $8(63.6)$ & $156.9 \pm 14.6$ & $3(27.3)$ & $66.6 \pm 8.8$ \\
\hline LLC & 35 & $10(28.6)$ & $7(70.0)$ & $181.4 \pm 18.3$ & $3(30.0)$ & $48.3 \pm 22.0$ \\
\hline
\end{tabular}

Conceptus shape is defined as in Degrelle et al. (20): filamentous ( $>15 \mathrm{~cm})$, early filamentous (Early Fil.) (10-15 cm), and tubular (3-10 cm). Filamentous and Early Fil. day (D)18 conceptuses are considered "fully elongated"; tubular D18 conceptuses are considered "delayed." AI, artificial insemination; GH, growing heifer. 
Table 4. Developmental stages of the conceptuses recovered at D18 after AI in GH, ELC, and LLC

\begin{tabular}{|c|c|c|c|c|c|c|}
\hline \multirow[b]{2}{*}{ Group } & \multirow[b]{2}{*}{ Conceptus, $n$} & \multirow[b]{2}{*}{ Staged Conceptus, $n$} & \multicolumn{4}{|c|}{ Observed Gastrulating Stages } \\
\hline & & & On the Disc & On the EET & On the Disc & On the EET \\
\hline ELC & 11 & 11 (including $1 \mathrm{Ab}$ ) & 6 & $2+1 \mathrm{UD}$ & 1 & \\
\hline LLC & 10 & 10 (including $1 \mathrm{Ab}$ ) & 4 & 1 & 3 & 1 \\
\hline
\end{tabular}

Embryonic stages are defined as expected D18 stages, i.e., late streak (or stage 4) and early streak (or stage 3). Younger discs harboring no streak but a posterior pole gastrulated properly but were delayed, whereas abnormal ones were called "Ab" when the gastrulating pattern was atypical. These stages were determined on the discs or on the extraembryonic tissue (EET), as detailed in Degrelle et al. (20, 21). UD, undetermined; TV, trophoblastic vesicles.

comparisons: TSPO and $C A P G$. The translocator protein gene $(T S P O)$ is a key factor in the flow of cholesterol into mitochondria to allow the initiation of steroid hormone synthesis (60). This gene was downregulated in GH vs. ELC and LLC and upregulated in ELC vs. LLC. The capping protein (actin filament) gelsolin-like (CAPG) encodes a member of the actinregulatory proteins that may play a role in regulating cytoplasmic and/or nuclear structures in epithelial cells $(4,53)$. This gene was downregulated in GH vs. ELC and LLC and upregulated in ELC vs. LLC. Finally, most of the DEG appeared specific to each comparisons with 201, 197, and 27 differences between, respectively, heifers vs. ELC, heifers vs. LLC and ELC vs. LLC.

When the whole set of DEG is considered, the top biological functions that emerged at first glance as differential among these three groups of EET, after in silico analysis with the IPA software, were all linked to development and metabolism (Table 5). As for development, three main groups of functions appeared, namely those related to 1 ) connective tissue development ( $B G N, C O L, C T G F, D C N)$, redox homeostasis (TXDNDC9), or EET differentiation (PTGDS, PTGES, SPP1, PAG11, PAG12); 2) embryonic patterning (FURIN); and
Fig. 3. Sources of variability of gene expression in the conceptuses. Gene expression variability related to: dam physiological status $(\mathrm{GH} n=8, \operatorname{ELC} n=11, \operatorname{LLC} n=10)$ (A), conceptus sex (male $n=17$, female $n=$ 12) $(B)$, conceptus size [filamentous and early filamentous (fil.) $n=21$, tubular (tub.) $n=71(C)$, developmental stage of the embryonic disc (expected at D18: stages 3 and $4, n=11$; younger than D18: stage $2, n=$ 10) $(D)$. The number of extraembryonic tissues (EET) in each Principal Component Analysis is the merge between the EET that were used in the transcriptomic analysis and the observed variables for those EET (the merge is complete in $A, B, C$, where $n=29$ but incomplete for $D$ since embryonic discs were not found for the $29 \mathrm{EET}$, indeed with a disc, $n=23$ ). d, Euclidean distance for normalized and centered data.
A Dam physiological status effect

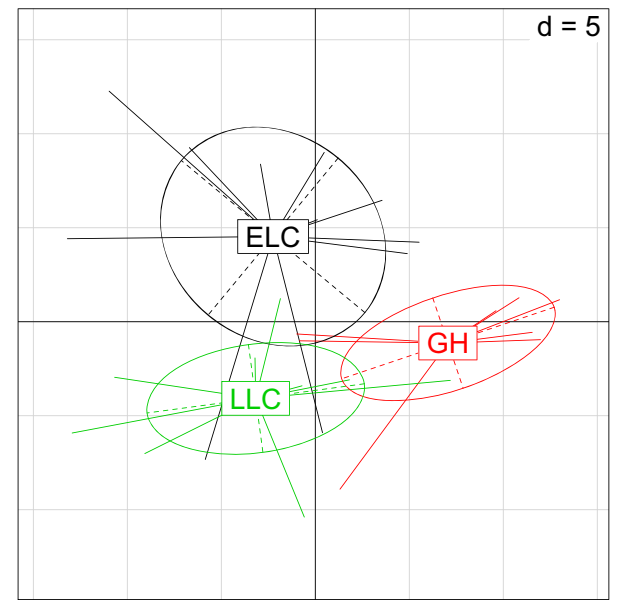

C Elongation effect

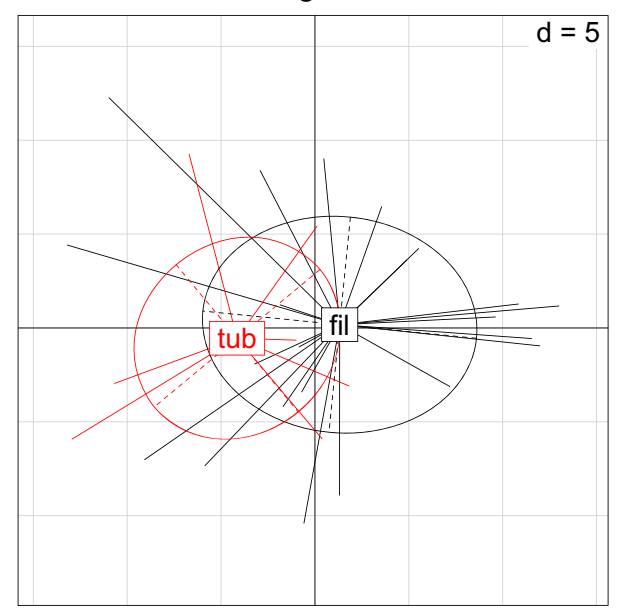

B Sex of the embryo effect

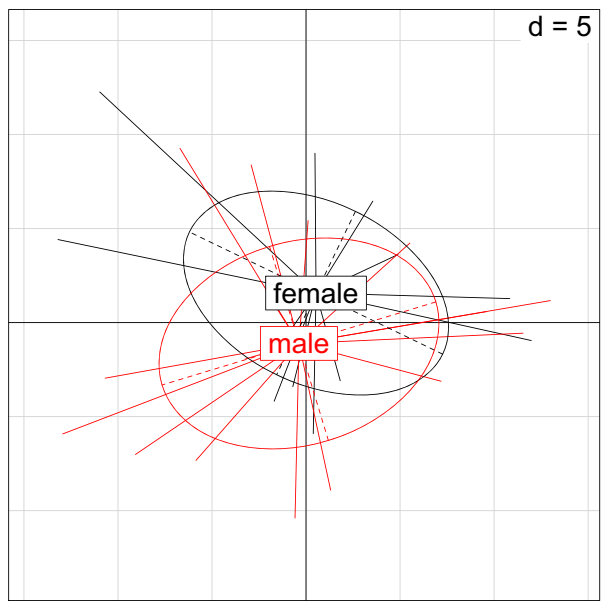

D Embryonic Disc effect

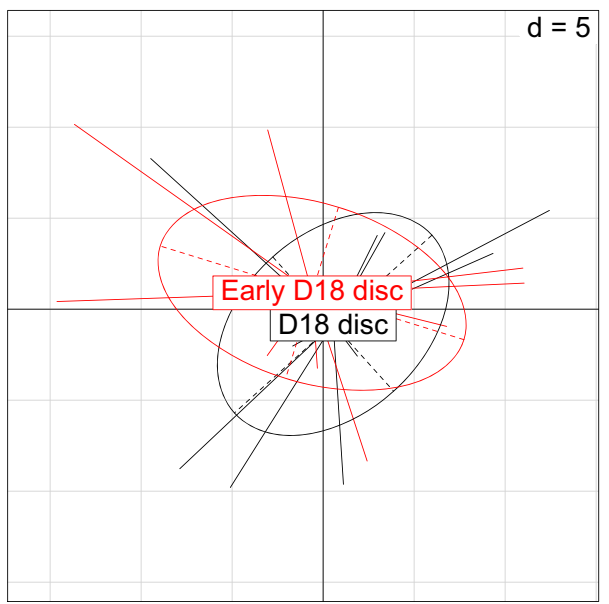



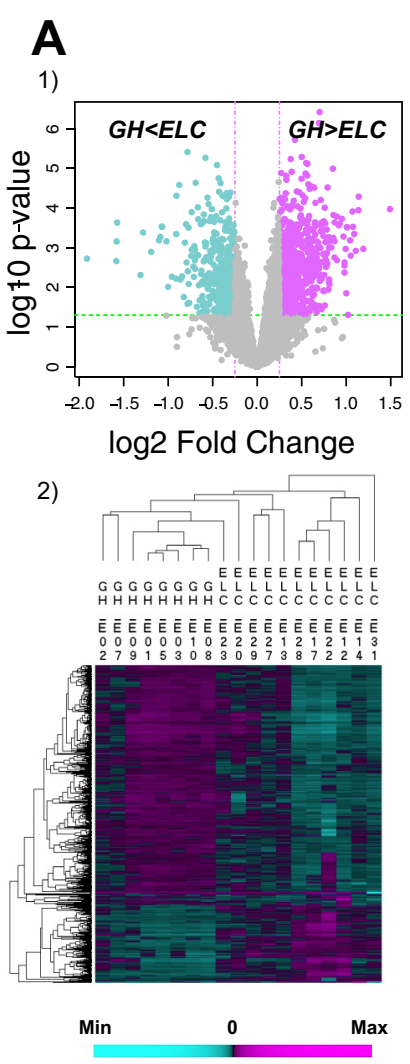

333 DEG
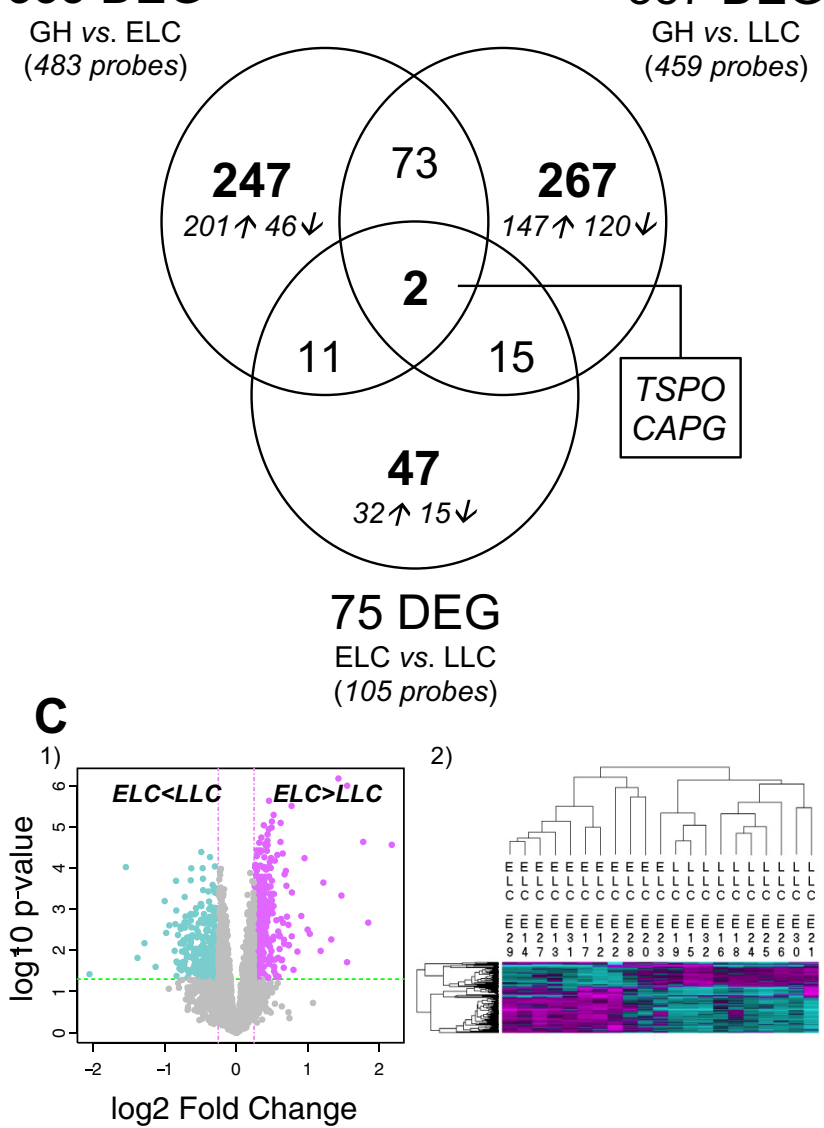

B

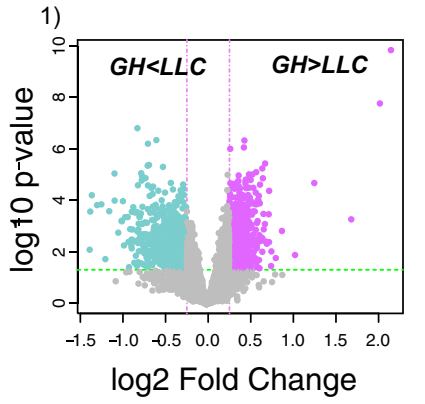

2)

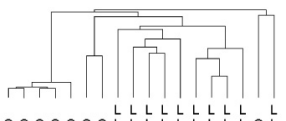

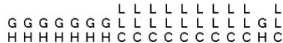

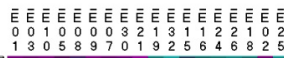

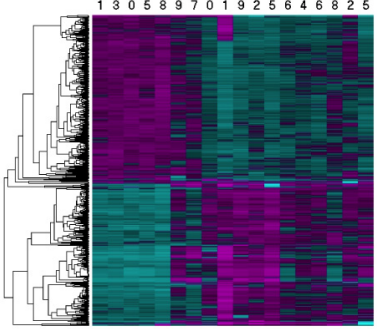

Fig. 4. Classical differential analysis of gene expression in the conceptuses. Differentially expressed genes (DEG) between EET of D18 conceptuses collected in GH $(n=8)$, ELC $(n=11)$, and LLC $(n=10)$. A Venn diagram compares the DEG of EET of GH vs. ELC, GH vs. LLC, and ELC vs. LLC. Each comparison is illustrated by a hierarchical clustering (PermutMatrix, Pearson's distance) of the DEG, EET, and dam physiological status. Volcano plots present the fold changes in gene expression for the 3 comparisons. Gene and probe numbers differ due to repeated spotting and/or missing annotation.

3) chromatin remodeling via effector molecules that modify histone marks (TDRD3) and thus lead to gene activation (SMARCA1, SMARCA2, SMARCB1) or repression (EHMT2).

Moreover, since the physiological status of the dams explained $23.7 \%$ of the variability observed in the overall gene expression pattern of these D18 EET, we further investigated correlations between the whole set of differentially expressed probes and the metabolic/hormonal patterns related to preinsemination and early pregnancy energy status of the dams (Fig. 5, $A-C)$. Using two-dimensional RCCA, we selected 214 probes within the GH vs. ELC comparison, among which 163 were annotated. Similarly, 342 probes ( 255 annotated) and 16 probes (11 annotated) were highlighted from the GH vs. LLC and ELC vs. LLC comparisons. The variations as well as the mean level of IGF-1 in the blood before embryo flush were the main factors that were correlated $(|r|>0.6)$ with EET gene expression differences between heifers and lactating cows (ELC, 189 probes; LLC, 196 probes). Mean NEFA and urea concentrations were both correlated with one annotated gene (TKT) in GH vs. ELC and with a few probes in GH vs. LLC (with $n=$ $38, n=14$ probes, respectively). The postpartum variations in
NEFA and urea were also linked to some probes in the GH vs. LLC comparisons ( $n=23, n=78$, respectively). The postpartum variations and the mean of metabolites/hormones measured were not significantly correlated with EET gene expression differences between the two groups of lactating cows $(|r|<0.6)$. However, we created a small dataset with a $|r|$ superior to 0.3 for this comparison.

\section{Expression of Genes Involved in Lipid and Energy}

Metabolism Is Affected in Relation to Dam Physiological Status

To characterize the functions of the DEG linked by RCCA with the metabolic/hormonal patterns of the dams, we focused mainly on the prominent pathways that were affected in GH vs. ELC and GH vs. LLC comparisons, based on IPA significance thresholds. The outcome was that pathways related to energy and lipid metabolism were affected in both cases. Only two genes were implicated in metabolic functions of the conceptuses in the comparison between ELC and LLC. Developmental pathways were affected too, mostly within the GH vs. ELC 
Table 5. Top functions highlighted among the whole set of DEG in D18 EET from GH $(n=11)$ and lactating cows $(E L C$, $n=11 ; L L C, n=10$ )

\begin{tabular}{|c|c|c|c|}
\hline $\begin{array}{l}\text { Top Functions (IPA } \\
\text { score }>20 \text { ) }\end{array}$ & GH vs. ELC & GH vs. LLC & ELC vs. LLC \\
\hline \multirow[t]{2}{*}{ Cellular development } & $\begin{array}{l}2 \text { networks, } 46 \text { DEG } \\
\uparrow A F G 3 L 2, \text { SMARCA2 }\end{array}$ & & $\begin{array}{l}2 \text { networks, } 27 \text { DEG } \\
\uparrow A R F G E F 2, C A P G, \\
\text { HAND1, PGF, RBP4 }\end{array}$ \\
\hline & $\downarrow F U R I N$ & & $\downarrow T X N D C 9$ \\
\hline \multirow[t]{2}{*}{ Tissue development } & $\begin{array}{l}1 \text { network, } 21 \text { DEG } \\
\uparrow \text { BGN, COL18A1, CTGF DCN, PTGES, SPP1 }\end{array}$ & $\begin{array}{l}1 \text { network, } 25 \text { DEG } \\
\uparrow \text { COL18A1, HNRNPDL, SMARCB1, } \\
\text { PAG11, PAG12 }\end{array}$ & \\
\hline & $\downarrow H 2 A F V$ & $\downarrow H A N D 1$, NIPA2 & \\
\hline Metabolic disease & & $\begin{array}{l}1 \text { network, } 30 \text { DEG } \\
\uparrow \text { NDUFA9 } \\
\downarrow \text { EHMT2, H2AFX }\end{array}$ & \\
\hline \multirow[t]{2}{*}{ Lipid metabolism } & $\begin{array}{l}1 \text { network, } 16 \text { DEG } \\
\uparrow \text { APOE, LIPA, PTGDS, SMARCA1, TDRD3 }\end{array}$ & $\begin{array}{l}3 \text { networks, } 46 \text { DEG } \\
\uparrow \begin{array}{l}\text { APLP1, APOE, LIPA, PTGDS, SMARCA2, } \\
\text { TDRD3 }\end{array}\end{array}$ & $\begin{array}{l}1 \text { network, } 16 \text { DEG } \\
\uparrow T S P O\end{array}$ \\
\hline & $\downarrow T S P O$ & 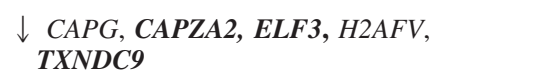 & $\downarrow A P O E$ \\
\hline
\end{tabular}

In addition to gene networks and DEG numbers, are some of the DEG. Boldface shows genes involved in development. $\uparrow$, upregulated DEG; $\downarrow$, downregulated DEG.

and GH vs. LLC comparisons. Among them, several DEG were known for their expression in elongating EET (CAPZA2, COLI8A1, FURIN, HANDI, PAG11, PAG12, PTGES, PTGDS, $S P P 1$; reviewed in Refs. 33, 48, also see Ref. 68), but few were new at that stage $(C T G F, E L F 3, P G F)$. We thus further focused on metabolic pathways.

$G H$ vs. ELC. The first canonical pathways related to these DEG were involved in energy and lipid metabolism, namely: acetate conversion to acetyl-CoA ( $\uparrow$ ACSS2, $\uparrow$ ACSS3), prostanoid biosynthesis ( $\uparrow P T G D S, \uparrow P T G E S)$, pentose phosphate pathway ( $\uparrow P G D, \uparrow T K T)$, and fructose biosynthesis $(\downarrow G M D S)$.
Moreover, the first top diseases and disorders associated with the functions of these DEG corresponded to metabolic diseases such as: experimentally induced diabetes $(\uparrow C S D A, \uparrow D U S P 1$, $\uparrow P D L I M 4, \quad \uparrow P R K C D)$, cholesteryl ester storage disease ( $\uparrow L I P A$ ), glucose transporter (Glut1) deficiency syndrome type 2 $(\uparrow S L C 2 A 1)$, pyruvate carboxylase deficiency disease $(\uparrow P C)$, and adiposity ( $\uparrow D Y N C 1 H 1, \uparrow G P X 1, \uparrow T H R A, \uparrow T K T)$.

Many top molecular and cellular functions were also associated with lipid metabolism and are presented in Table 6. In brief, the metabolism, concentration, synthesis, cleavage, conversion, and release of lipids including metabolism of prostaglandins within the EET were related to the females' energy
A
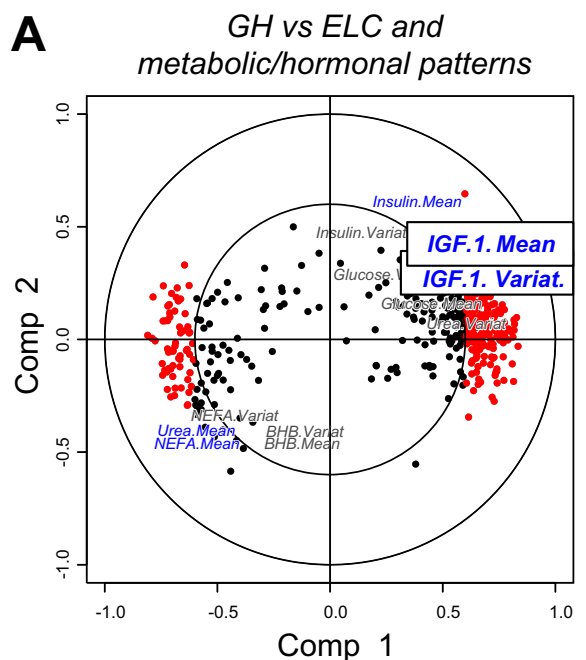

B

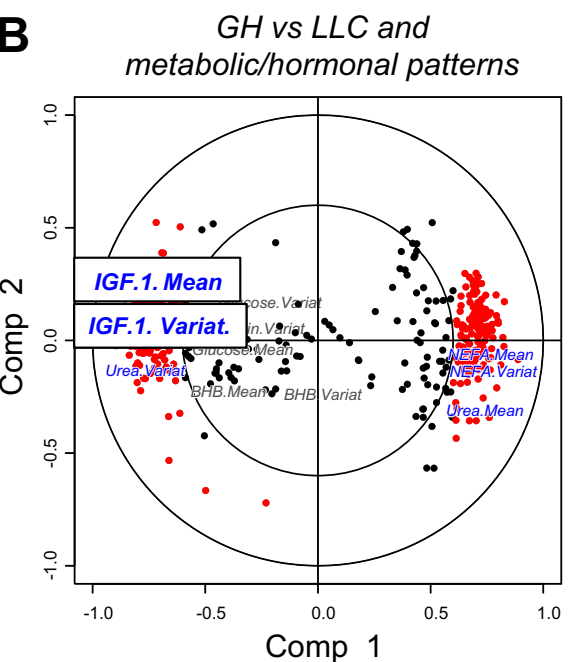

C ELC vs LLC and metabolic/hormonal patterns

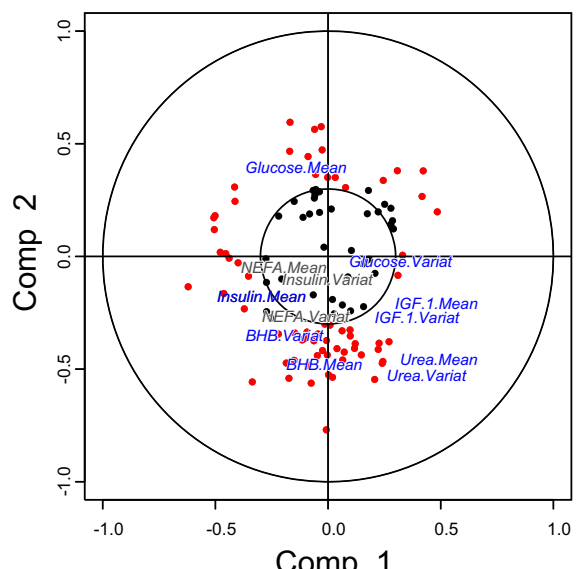

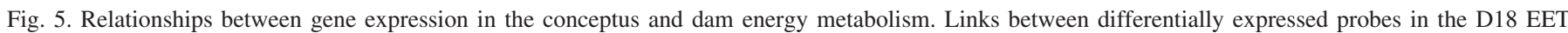

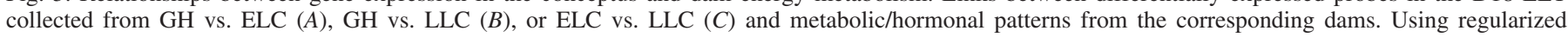

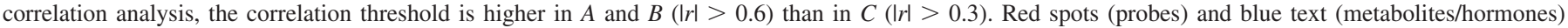

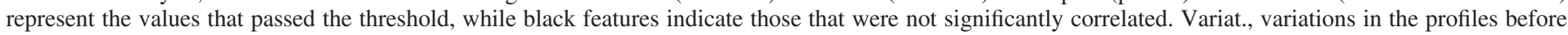
embryo flush. 
Table 6. Top 10 functions related to DEG in D18 EET from GH, ELC, and LLC associated with lipid metabolism functions

\begin{tabular}{|c|c|c|c|c|}
\hline Comparisons & Molecules & Function Annotation & $P$ Value & Molecules, $n$ \\
\hline GH vs. ELC & 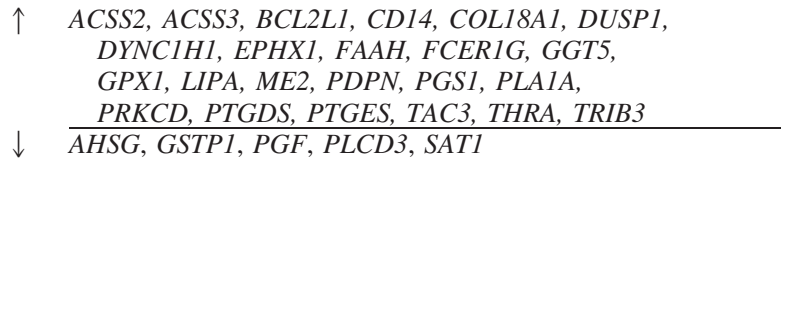 & $\begin{array}{l}\text { fatty acid metabolism } \\
\text { concentration of lipid } \\
\text { synthesis of lipid } \\
\text { concentration of fatty acid } \\
\text { synthesis of fatty acid } \\
\text { metabolism of eicosanoid } \\
\text { cleavage of lipid } \\
\text { conversion of lipid } \\
\text { release of lipid } \\
\text { metabolism of prostaglandin }\end{array}$ & $\begin{array}{l}1.53 \mathrm{E}-04 \\
1.69 \mathrm{E}-02 \\
1.22 \mathrm{E}-02 \\
3.30 \mathrm{E}-04 \\
3.73 \mathrm{E}-04 \\
1.48 \mathrm{E}-03 \\
4.36 \mathrm{E}-03 \\
7.30 \mathrm{E}-04 \\
5.47 \mathrm{E}-03 \\
6.06 \mathrm{E}-03\end{array}$ & $\begin{array}{r}14 \\
13 \\
12 \\
9 \\
9 \\
7 \\
7 \\
6 \\
6 \\
5\end{array}$ \\
\hline GH vs. LLC & $\begin{array}{ll}\uparrow & C A C N A 1 H, C E R S 2, C N T F, C O T L 1, E P H X 1, F C E R 1 G, G S N, \\
& I G F B P 4, P G S 1, P R K C D, S G P P 1 \\
\downarrow & C E R S 5, C H K A, C L N 3, D B I, G G T 5, M V K, S L C 35 A 2, L P C A T 3\end{array}$ & $\begin{array}{l}\text { synthesis of lipid } \\
\text { fatty acid metabolism } \\
\text { metabolism of glycosphingolipid } \\
\text { synthesis of glycosphingolipid } \\
\text { synthesis of ceramide } \\
\text { synthesis of leukotriene } \\
\text { synthesis of D-erythro-C16-ceramide } \\
\text { metabolism of sphingomyelin } \\
\text { metabolism of ceramide } \\
\text { transport of taurocholic acid }\end{array}$ & $\begin{array}{l}2.27 \mathrm{E}-02 \\
6.62 \mathrm{E}-03 \\
6.18 \mathrm{E}-03 \\
1.42 \mathrm{E}-02 \\
1.88 \mathrm{E}-02 \\
2.50 \mathrm{E}-02 \\
3.48 \mathrm{E}-04 \\
2.37 \mathrm{E}-03 \\
8.43 \mathrm{E}-03 \\
1.60 \mathrm{E}-02\end{array}$ & $\begin{array}{r}16 \\
14 \\
5 \\
4 \\
3 \\
3 \\
2 \\
2 \\
2 \\
2\end{array}$ \\
\hline ELC vs. LLC & $\uparrow \quad \frac{R B P 4}{H M O X 1}$ & $\begin{array}{l}\text { fatty acid metabolism } \\
\text { transport of retinol } \\
\text { abnormal quantity of retinol } \\
\text { concentration of 6-keto-prostaglandin F1 } \alpha \\
\text { synthesis of epoprostenol } \\
\text { metabolism of retinol } \\
\text { concentration of prostaglandin E2 } \\
\text { peroxidation of lipid }\end{array}$ & $\begin{array}{l}2.49 \mathrm{E}-02 \\
4.22 \mathrm{E}-04 \\
2.95 \mathrm{E}-03 \\
4.21 \mathrm{E}-03 \\
7.56 \mathrm{E}-03 \\
1.17 \mathrm{E}-02 \\
1.51 \mathrm{E}-02 \\
2.05 \mathrm{E}-02\end{array}$ & $\begin{array}{l}2 \\
1 \\
1 \\
1 \\
1 \\
1 \\
1 \\
1 \\
1\end{array}$ \\
\hline
\end{tabular}

Those were selected as being statistically correlated with blood metabolic/hormonal patterns of the dams before embryo flush (especially IGF-1 and NEFA, $|r|>0.6$ in heifers vs. cows comparison, $|r|>0.3$ in cows comparison).

status. Moreover, genes involved in the regulation of triacylglycerol ( $\downarrow A H S G)$, mitochondrial GTP/ATP phosphotransferase ( $\uparrow A K 3)$, ATPases ( $\uparrow A T P 4 A, \downarrow A T P 6 V 1 F, \uparrow P I C K 1)$, genes of oxidation-reduction process in mitochondria and gluconeogenesis ( $\uparrow M E 2)$, mitochondrial components ( $\uparrow M S S 51$, $\uparrow$ MTHFD2, $\downarrow$ GSTP1, $\uparrow$ GPX1), genes of electron transport chain ( $\uparrow N D U F C 2$ ), of cell redox homeostasis ( $\downarrow Q S Q X 1)$, and (among other transporters) the major glucose transporter $(\uparrow S L C 2 A 1)$ or a StAR-related lipid transporter ( $\downarrow S T A R D 10)$ highlighted other aspects of the energy metabolism that are affected in the D18 EET in addition to lipid metabolism.

$G H$ vs. LLC. Here, the main canonical pathways involved were those of lipid mitochondrial (cardiolipin) biosynthesis ( $\uparrow P G S 1)$, glycolysis ( $\downarrow P G K 1, \downarrow T P I 1)$, fatty acid $\beta$-oxidation $(\downarrow H S D 17 B 10, \downarrow I V D)$, leptin signaling in obesity ( $\uparrow$ GNAS, $\downarrow G R B 2, \downarrow P L C D 3)$, pyruvate conversion to lactate ( $(\mathrm{LDHB})$, GDP glucose biosynthesis, glucose, and glucose I phosphate degradation ( $\uparrow H K 1$ ), sucrose degradation ( $\downarrow T P I 1)$, and IGF-1 signaling ( $\downarrow G R B 2, \uparrow I G F B P 4, \uparrow Y W H A B)$. Shared with the GH vs. ELC comparison were also fructose biosynthesis $(\downarrow G M D S)$ and the pentose phosphate pathway ( $\uparrow T K T)$. Synthesis, metabolism, transport, and accumulation of lipids were also related here with the dams' energy status (Table 6). We also found additional genes involved in energy metabolism such as acyl-CoA dehydrogenase in mitochondria ( $\downarrow A C A D S$ ), ATP-related genes ( $\uparrow A T P 4 A, \uparrow A T P 6 V 1 D, \uparrow A T P I F 1)$, ATP-binder in mitochondria ( $\uparrow A K 2, \uparrow A K 3$ ), ATP-catabolism gene ( $\uparrow O L A 1$ ), mitochondrial respiratory chain transporter-related genes ( $\uparrow$ NDUFA9, $\uparrow O X A 1 L$ ), mitochondrial proteins encoding genes ( $\downarrow$ MRPS30, $\downarrow$ MRPSO), ADP-related genes ( $\downarrow$ ARFRP1), GTP- related gene ( $\uparrow G T P B P 2)$, carbohydrate biosynthesis gene $(\downarrow N A N S)$, lipid biosynthesis ATP-binder $(\downarrow M V K)$, lipid hydrolysis ( $\downarrow P L C D 3)$, and many transporters involved in cell nutrition and function (e.g., $\downarrow S L C 35 A 2$, UDP-galactose transporter; and $\uparrow S L C 25 A 28$, mitochondrial iron transporter).

ELC vs. LLC. Within the small set of DEG associated by RCCA ( $|r|>0.3,11$ annotated) to the circulating metabolites/ hormones of the dams, the first top disease and disorder that was identified was a metabolic disease. Some of these genes were also linked to lipid metabolism (Table 6). Of special interest were those related to ADP-ATP ( $\uparrow A R F G E F 2$, $\uparrow A T P I F 1$ ) or retinol and fatty acid transport ( $\uparrow R B P 4)$. Acting also as an adipocytokine for lipomobilization from the adipose tissue, $R B P 4$ was one of the genes that we were validating by $\mathrm{RT}-\mathrm{qPCR}$.

Indeed, in support of these in silico analyses, a small set of 16 genes was selected for technical validations ( $A B C G 2$, APOE, ATP6VID, CTGF, DBI, ELF3, IGFBP4, LIPA, NDUFA1, NDUFC2, NDUFS6, PC, PGF, RBP4, SLC2A1, $S T A R D 10)$. Among these, 12 were significantly correlated to the circulating metabolites/hormones of the dams, and four were not (ABCG2, APOE, NDUFA1, NDUFS6). Most were involved in metabolic pathways (13/16), although a few (3/16) in developmental ones. To our knowledge, CTGF, ELF3, and $P G F$ have not been analyzed so far in bovine D18 EET. Twelve expression patterns out of 16 were biologically validated on a batch of the 15 fully elongated EET harboring properly gastrulated D18 embryonic discs. On these D18 EET, most of the selected genes related to the metabolism in the EET and to the dam energy status were validated (75\%; Table 7: 4 
out of 7 from the GH vs. ELC comparison, 7 out of 8 from the GH vs. LLC comparison, and 1 out of 2 from the ELC vs. LLC comparison). As observed on the microarray dataset, 1) LIPA, $C T G F$, and SLC2Al were more and STARD10 less expressed in D18 EET from GH than ELC, 2) IGFBP4, ABCG2, and ATP6V1D were more and NDUFS6, NDUFC2, NDUFA1, and $D B I$ less expressed in D18 EET from GH than LLC, and 3) RBP4 was more expressed in D18 EET from ELC than LLC. We only had difficulties in validating the genes encoding APOE, ELF3, $P C$, and $P G F$ (data not shown). For APOE, we excluded the possibility that this was due to the 14 EET that were not used in the validations. The minimum and maximum expression values for this gene were indeed not different among the 29 EET of the study. For $P C$ and $P G F$, this could be due to EET that were not included in the validations and were outliers. As for ELF3, the overall range of expression of this gene may explain that, conversely to the array data, these gene expression differences were normalized against a small set of housekeeping genes and were thus not as statistically significant.

\section{DISCUSSION}

\section{Dam Energy Metabolism}

In this experiment, three groups of cows in different energy statuses before conceptus recovery were successfully created. Lactating cows experienced a period of NEB after calving, typically associated with low circulating concentrations of glucose, insulin, and IGF-1 and high concentrations of NEFA and BHB, both products of fatty acid metabolism (76). As lactation progresses, voluntary feed intake increased and NEB was reduced. Therefore, in the present experiment, ELC were initially in a strong NEB (losing BCS) that gradually evolved to be a slight NEB at conceptus collection, whereas LLC were in a slight NEB initially (9 wk before embryo collection) that became balanced just before conceptus collection (BCS nearly constant over the period). GH were nearly in the same EB situation as the LLC group, where energy intake equaled energy output (either as milk synthesis or as muscle growth). Heifers had high circulating concentrations of glucose, insulin, and IGF-1 and low concentrations of NEFA and BHB as previously observed by our research group in Holstein heifers with a comparable daily weight gain $(25,56)$. The big differences between the heifers and the cows were the IGF-1 concentrations: they were $\sim 10$ fold higher in the growing than in the lactating animals. During the free-life of the conceptuses, i.e., between AI and flushing of the uterus at D18, energy statuses were clearly different between heifers and cows but were closely similar between ELC and LLC.

\section{Conceptus Recovery Rates}

In the Holstein breed in France, calving rate after first $\mathrm{AI}$ is $57 \%$ in heifers, $40 \%$ in primiparous cows, and $35 \%$ in thirdlactating cows (39). In our experiment, conceptus recovery rates at D18 were similar to pregnancy rates observed in commercial herds for our heifers (58\%) but lower in our multiparous cows (23\% after first $\mathrm{AI}$ and $29 \%$ after second $\mathrm{AI}$ ) even if measured on D18 after AI (i.e., before late embryonic and fetal death). This can be due to a recovery rate $<100 \%$. The same team have obtained an embryo recovery rate (number of embryos/number of corpus luteum) of 39\% between D6 and D9 after AI ( $n=145$ flushes) and $44 \%$ between D12 and D21 $(n=251$ flushes) in superovulated cows (58), but we have to consider that early embryonic mortality might have occurred before D12 even in superovulated cows. Embryo recovery rate might be close to pregnancy rate at late stage when the embryo is large. Moreover, first service conception rate is usually low in this herd: $29 \%$ measured on D60 after AI (41). Additionally, the low embryo recovery rate in the cows can be partly explained by the calving-to-first-AI interval, which was lower in our experiment (63 days) compared with commercial French dairy herds (ranging between 85 and 95 days over the years 2000 and 2008) and to high postpartum loss of BCS, which is sometimes (but not always) related to low pregnancy rates in dairy cows (45). Nevertheless, we observed the expected difference in fertility between virgin heifers in adequate BCS at breeding (recommendation 2.5) and multiparous lactating cows, which is classically attributed to higher fertilization rate and lower embryonic loss in heifers compared with lactating cows $(22,62)$.

\section{Dam Group Effect on Conceptus Recovery Rate}

The dam group effect on recovery rate might be related to some known variation factors of fertility between the two groups (heifers vs. cows) of females: age/parity (heifers are close to puberty vs. older multiparous cows), uterine health and

Table 7. Validation of 12 gene expression differences in D18 EET from GH, ELC, and LLC

\begin{tabular}{|c|c|c|c|c|c|c|c|}
\hline Comparison & Gene Name & \multicolumn{3}{|c|}{ Differential Analysis } & \multicolumn{3}{|c|}{ RT-qPCR } \\
\hline \multirow[t]{3}{*}{ GH vs. ELC } & LIPA & $\mathrm{GH}>\mathrm{ELC}$ & 1.57 & $<0.05$ & $\mathrm{GH}>\mathrm{ELC}$ & 1.78 & 0.01 \\
\hline & $S L C 2 A 1$ & $\mathrm{GH}>\mathrm{ELC}$ & 1.29 & $<0.05$ & $\mathrm{GH}>\mathrm{ELC}$ & 1.10 & 0.12 \\
\hline & STARD10 & $\mathrm{ELC}>\mathrm{GH}$ & 1.41 & $<0.05$ & $\mathrm{ELC}>\mathrm{GH}$ & 1.44 & 0.03 \\
\hline \multirow{5}{*}{ GH vs. LLC } & $I G F B P 4$ & $\mathrm{GH}>\mathrm{LLC}$ & 1.5 & $<0.05$ & $\mathrm{GH}>\mathrm{LLC}$ & 1.19 & 0.07 \\
\hline & $A B C G 2$ & $\mathrm{GH}>\mathrm{LLC}$ & 1.39 & $<0.05$ & $\mathrm{GH}>\mathrm{LLC}$ & 1.14 & 0.07 \\
\hline & NDUFC2 & $\mathrm{LLC}>\mathrm{GH}$ & 1.36 & $<0.05$ & LLC $>$ GH & 1.22 & 0.04 \\
\hline & NDUFA1 & $\mathrm{LLC}>\mathrm{GH}$ & 1.28 & $<0.05$ & LLC $>$ GH & 1.14 & 0.06 \\
\hline & $D B I$ & $\mathrm{LLC}>\mathrm{GH}$ & 1.60 & $<0.05$ & $\mathrm{LLC}>\mathrm{GH}$ & 1.06 & 0.10 \\
\hline ELC vs. LLC & $R B P 4$ & $\mathrm{ELC}>\mathrm{LLC}$ & 1.44 & $<0.05$ & $\mathrm{ELC}>\mathrm{LLC}$ & 1.10 & 0.09 \\
\hline
\end{tabular}

We tested 15 D18 EET (5 per group: GH, ELC, LLC). FDR, false discovery rate. 
integrity (nulliparous heifers vs. postpartum cows), physiological stage (nonlactating vs. lactating), diet protein supply, and EB.

The parity effect had a profound impact on early embryonic mortality in our experiment. Fertilization rate is supposed to be high in heifers $(>90 \%)$ and in lactating dairy cows $(75-80 \%$, Refs. 62, 70). Early embryonic mortality would have occurred in our three groups of cows but to a greater extent in cows than in heifers. Three hypotheses are used to explain the high incidence of early embryonic loss in high-producing dairy cows: 1) poor oocyte quality, 2) impaired ability of the genital tract to ensure conceptus development, and 3 ) low progesterone concentrations before and after insemination.

Lactating cows were in an NEB before AI. This is expected to have a detrimental effect on oocyte quality and to impair fertilization rate and early conceptus development, which might have an effect on later gene expression, at D18 $(43,44)$.

Moreover, we recently showed that postpartum nutritional stress alters gene expression in the oviduct to a larger extent than in the endometrium (70). This supports the hypothesis that NEB may mainly affect fertilization rate and very early (D0D7) rather than later (D7-D18) embryonic development by modifying the oviductal environment in the cow. In the heifer group, most of the conceptuses survived after D7 since we identified three trophoblastic vesicles and 11 conceptuses in the 19 females. This is in agreement with the observations of Rizos et al. (59) and Maillo et al. (47), who observed that the reproductive tract of lactating primiparous cows is less capable of supporting early embryonic development (D2-D7) compared with heifers or nonlactating cows.

Protein supply was higher in cows than in heifers and led to higher circulating urea concentrations, but they remained lower than the value of $7.14 \mathrm{mmol} / \mathrm{l}$ (urea nitrogen $20 \mathrm{mg} / \mathrm{dl}$ ) considered being detrimental for fertility (44).

Moreover, it is possible that some of our cows were affected by subclinical endometritis, which is known to have a detrimental effect on fertility (73). Some of them were assisted at calving, and some of them presented delayed uterine involution.

Circulating concentrations of $\mathrm{P} 4$ during the cycle prior to insemination and between 4 and $7 \mathrm{dpi}$ are related to conceptus survival $(22,61)$. In our experimental design, heifers and cows received a P4 analog supplement (Norgestomet) before AI; this is known to increase fertility (77). After AI, circulating concentrations of P4 were not different between pregnant heifers and pregnant lactating cows in our experiment. This is not consistent with the hypothesis that higher feed intake during lactation is associated with depressed circulating steroid concentrations due to greater hepatic clearance. However, our results are similar to those previously published by Maillo et al. (47) in lactating vs. dry cows. At D18, P4 concentrations were not correlated with conceptus development. This is not contradictory with the potential positive effect of high $\mathrm{P} 4$ on improved conceptus survival: low P4 concentrations might be involved in very early embryonic death (between D2 and D13), and we did not observe these animals in the present study since they were found to be nonpregnant on D18.

Cows and heifers did not receive the same treatment before insemination: eCG was used in cows but not in heifers as recommended by the laboratory to prevent multiple ovulations in young (and light) animals. This modified the endocrine milieu during early embryo development and might have had an effect on conceptus gene expression on D18. It may also mask the poorer fertility usually observed in cows vs. heifers since this hormone is known to have a positive effect on pregnancy rate after treatment.

\section{Dam Group Effect on Conceptus Development}

In our experiment, the development of the conceptuses that survived up to D18 was similar between the three groups of dams with: 1) almost all being elongated (only 2/32 were atypically small for D18 conceptuses) and 2) similar ratios of filamentous to tubular conceptuses per group. Similarly most embryonic discs displayed a normal gastrulating pattern (only $2 / 29$ were atypical). The ability of the uterus to sustain conceptus development between D13/D14 and D18 might thus be considered equivalent in heifers and lactating cows.

The length of D18 bovine conceptuses has often been recorded to be between 17 and $25 \mathrm{~cm}$. This was observed by Degrelle et al. (20), Thompson et al. (66), as well as in many earlier reports $(9,31,46)$. Accordingly, in the present experiment most of the conceptuses were properly elongated. However, even in heifers, some of them were early filamentous (length between 10 and $15 \mathrm{~cm}$ ) or tubular (length $<10 \mathrm{~cm}$ ). Indeed, the flush technique is susceptible to cause superficial damage to EET. Moreover, we used purebred Holstein females inseminated with a Holstein bull, whereas crossbred dairy and beef heifers were inseminated with various breeds of bulls to produce AI, IVP, and SCNT conceptuses in previous experiments $(8,17,20,49)$. Heterosis is known to be high for reproductive traits that are of low heritability $(51,64)$. Using such crossbreeding might thus have had an effect on early conceptus development. The effect of this practice should be investigated more carefully in the future.

\section{Dam Group Effect On Conceptus Gene Expression}

Gene expression differences were observed between the EET of our heifer vs. cow D18 conceptuses, though not more than $5 \%$ of the transcriptome assessed with our microarray (690 DEG out of 10,000 expressed genes in these D18 EET). The observed differences were mainly dealing with development and metabolism and were not all statistically correlated with the circulating concentrations of metabolites and hormones before embryo recovering.

As Betsha et al. (8) at D16 or Degrelle et al. (20) at D18, we did not observe any effect of the sex of the conceptus on gene expression patterns of our D18 conceptuses. Moreover, the embryonic stage of the conceptus, determined by the morphology of embryonic disc or the expression pattern of a predictive set of six extraembryonic genes, only had a modest effect on gene expression. This is probably related to small differences in conceptus development after AI and was also observed by Mamo et al. (49) while comparing transcripts between D16 and D19 conceptuses.

The expression of many DEG was correlated with metabolic/hormonal patterns before embryo flush but not all of them. The observed correlations were strong with circulating IGF-1 and NEFA concentrations, which were the parameters the most different between heifers and cows. However, we cannot exclude that confounding factors (cited above) may also have had a substantial effect on conceptus gene expression. Nevertheless, energy status might explain a considerable part of the 
differences observed in the expression of genes involved in developmental, carbohydrate, and lipid metabolism pathways.

The cow group effect (ELC vs. LLC) on gene expression was lower than the parity effect (GH vs. ELC and GH vs. LLC): only 75 genes were affected vs. 333 and 357 in the GH vs. cow comparisons. The LLC did not differ from ELC for $\mathrm{BCS}, \mathrm{BW}$ at calving and at breeding, peak milk production, nor milk production at breeding. However, LLC had a higher genetic merit for milk production than ELC cows, which is known to be negatively related to fertility (10). The difference in conceptus gene expression might reflect these differences in innate fertility. These two groups also differ in the calving to $\mathrm{AI}$ interval and in the fact that LLC received two vs. one estrus synchronization treatment. They were rebred after a uterine flush. These factors can lead us to consider LLC as being similar to repeat breeder cows. Surprisingly, neither calving assistance nor delayed uterine involution had a detrimental effect on fertility in our experiment: 36 and $40 \%$ of the pregnant cows were assisted at calving in the ELC and LLC groups, and among the five cows with delayed uterine involution, three were pregnant at first service (ELC) and one at the second service (LLC). Therefore, these last two factors cannot be considered as important variation factors of gene expression between our two groups of cows. Cows were in different EB before embryo flush, but this seems to have a lower impact on gene expression than variations between $\mathrm{GH}$ and lactating cows have (no strong correlations with metabolites/hormones patterns).

\section{Developmental Pathways Expressed in the Conceptuses}

Most of the genes affected are already well known and expressed within the temporal dynamics reported by Mamo et al. (49) between D7 and D19, as well as by others (reviewed in Refs. 33, 48, 68).

Indeed, connective tissue development is linked to EET development since proteins from the extracellular matrix (BGN, COL, DCN) contribute to the interactions with the underlying or overlying epithelial cells (mainly trophoblast cells in D18 EET). Conversely, based on the gene ontology database, the connective tissue growth factor (CTGF) regulates BGN and DCN synthesis but has broader functions in the regulation of cell growth, cell differentiation, or cell migration. Recently, it has also been predominantly observed in the trophectoderm of bovine blastocysts, as well as ELF3: an epithelial-specific transcription factor (55). HAND1, a transcription factor from another family, has also been associated with extraembryonic differentiation in bovine conceptuses after AI (18) or SCNT (2). In the present work, BGN, COL18Al, $D C N$, and $C T G F$ were more expressed in the D18 EET from heifers than from ELC, whereas HAND1 and ELF3 were less expressed in D18 EET from GH than LLC. Also involved in EET differentiation, and here more expressed in those from heifers than from lactating cows were the prostaglandin synthases (PTGDS, PTGES).

$P A G 11$ and PAG12, genes involved in prostaglandin synthesis, were affected by the dam group in our work and were recently described in D17 conceptuses by Thompson et al. (66). Last but not least, genes encoding proteins related to chromatin remodeling appeared either more expressed in EET from heifers (SMARC-A,B and TDRD3: activators of gene expression) or less expressed (EHMT2: negative regulator of transcription) than in cows. How these proteins relate to the physiological status of the dam and contribute to D18 EET differentiation awaits further studies. However, dam EB might be involved as observed in primates and rodents, where maternal nutrition has been shown to affect different developmental windows (even before embryo implantation) and different tissues, thus modifying both gene expression and epigenetic marks (for example Ref. 27).

\section{Metabolic Pathways Expressed in Conceptuses}

Comparative gene expression between GH and ELC is of great interest to understand variations in conceptus energy metabolism. The outcomes of the transcriptomic study were that differential gene expression patterns in D18 EET from ELC and LLC were mainly downregulations compared with those from heifers. Since genes affecting chromatin remodeling and leading to gene activation were less expressed in D18 EET from ELC and LLC than from GH (while those leading to gene repression were more expressed), it may be that this overall downregulation in ELC and LLC has an epigenetic origin.

Carbohydrate metabolism. Glucose, lactate, and pyruvate are used for energy production in early bovine conceptuses (67). In our experiment, circulating glucose concentrations were higher in GH than in ELC, and this was reflected in conceptus metabolism since for example gene expression of $S L C 2 A 1$, a glucose transporter, was upregulated in the conceptuses of GH. Glucose plays two roles for the conceptus: it is a potential source of ATP through the glycolysis pathway but also of ribose and NADPH through the pentose-phosphate pathway (67). Ribose synthesis is essential for conceptus development as this molecule is a precursor of DNA and RNA synthesis. Interestingly, we found this later pathway upregulated in GH vs. ELC conceptuses (upregulation of $P G D$ and $T K T$ genes). The exposure of the zygote to high levels of glucose was associated with an increase in gene expression associated with oxidative stress $(12,13)$. The fact that $S L C 2 A 1$ is overexpressed in the EET of D18 conceptuses from heifers in our experiment could thus indicate a state of higher metabolic activity but also of higher oxidative stress. Another way for the conceptus to produce energy is by oxidative phosphorylation via the oxidation of pyruvate and amino acids. In a comparison of GH vs. ELC conceptuses, the $P C$ gene, which encodes for pyruvate carboxylase (an enzyme that catalyzes the carboxylation of pyruvate to oxaloacetate, the main fuel for the citric acid cycle), is upregulated. In a comparison of GH vs. LLC, the $L D B H$ gene, also involved in pyruvate and lactate utilization, was upregulated.

ACSS2 and ACSS3 (acyl-CoA synthetase short-chain family member 2 and 3), upregulated in GH vs. ELC cows, are two enzymes found in the cytosol and mitochondria, respectively, that activate the utilization of acetate to produce acetyl-CoA for lipid synthesis or for energy production (75). Acetate is the major volatile fatty acid produced by ruminal fermentation. It is oxidized throughout most of the body to generate ATP, and it is the major source of acetyl CoA for lipid synthesis. To our knowledge, its availability in the uterus and its utilization by the peri-implanted conceptus have not been documented. 
Moreover, ATP4A, upregulated in GH vs. ELC and LLC cows, encodes for an enzyme that catalyzes the hydrolysis of ATP. The utilization of ATP appeared to be higher in GH than in cow conceptuses.

All these observations taken together sustain the same hypothesis: energy was more available in heifers than in cow conceptuses.

Lipid metabolism. Lipids and fatty acids are precursors for prostaglandin and steroid hormone biosynthesis. In our study, prostaglandin biosynthesis was upregulated in GH vs. ELC and LLC ( $\uparrow P T G D S, \uparrow P T G E S)$, but cholesterol transport was downregulated $(\downarrow T S P O)$. Lipids are included in cell membranes and provide substrate for energy production by the $\beta$-oxidation pathway (75). Gene expression was in favor of lipid utilization and synthesis in heifer vs. cow conceptuses as most of the DEG were upregulated in GH vs. ELC and LLC. Some genes implicated in the lipid hydrolysis and $\beta$-oxidation pathways were downregulated in heifers vs. LLC. This may signify that $\beta$-oxidation was more active in LLC than in GH conceptuses. Bovine oocyte and conceptuses sometimes have high concentrations of intracellular lipids, but this is suspected to have a detrimental effect on oocyte quality and on the developmental ability of the conceptus $(43,44)$. Little is known about the lipid content of uterine secretions around the day of implantation in the cow. Histotroph composition has been widely investigated in the ewe (review Ref. 5), but in this species breeding occurs after weaning and is not concomitant with postpartum lipolysis and NEB induced by lactation as seen in postpartum cows. Lipid utilization for energy metabolism was recently demonstrated in early in vitro cultured bovine embryos (77), but there are no data to our knowledge about peri-implantation embryos.
In summary, heifer conceptuses were engaged in many functions involving lipid biosynthesis as these pathways were upregulated compared with lactating cow conceptuses, which developed in a metabolic environment involved in lipolysis.

\section{Summarizing the Functions Influenced by Dam Physiological Status}

Gene expression in D18 EET influenced by the dam physiological status is totally new and appears associated with two main categories of functions: 1) development and 2) metabolism. Moreover, we found gene downregulations, in EET originating from ELC and LLC compared with GH, of a few genes from the epigenetic machinery. Thus, modifications of epigenetic marks must constitute a third category of functions affected by the dam physiology. This, however, has to be investigated further. In brief, the most significant genes identified in this study as susceptible to the dam physiological status are presented in Fig. 6. The expression of most genes is related to measured metabolic/hormonal patterns observed before conceptus collection, likely to EB. Nevertheless, as discussed above, we cannot exclude the effect of confounding factors such as: age of the dam, parity (nulliparous vs. multiparous), lactation, and differential reproductive history (assistance at calving, uterine health). All these factors might affect oocyte quality and oviductal and uterine environment and thus affect developing tissues of the embryos. Those modifications might influence the close or far "future" of the extraembryonic or embryonic tissues, the early placentation steps, but also the future germline. Modifications in epigenetic marks could indeed influence later performances at the adult stage, compris-
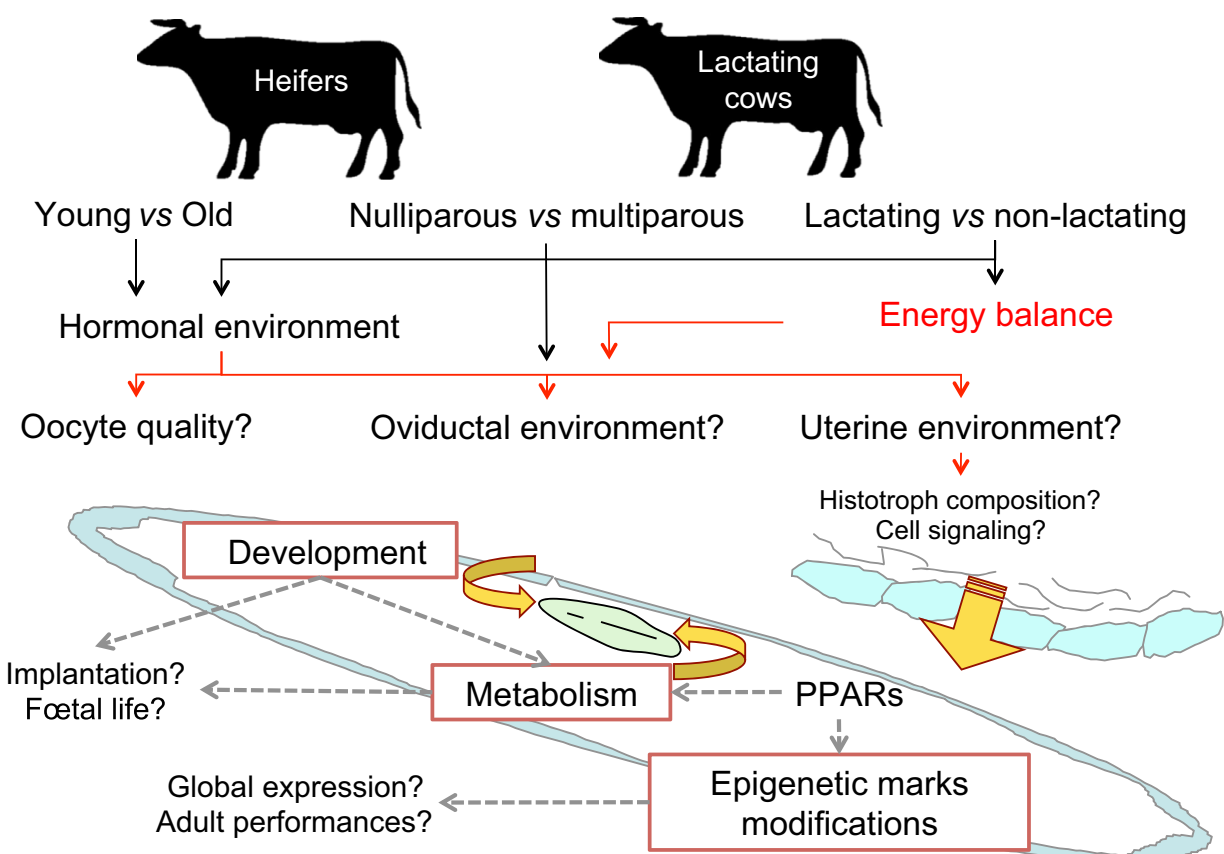

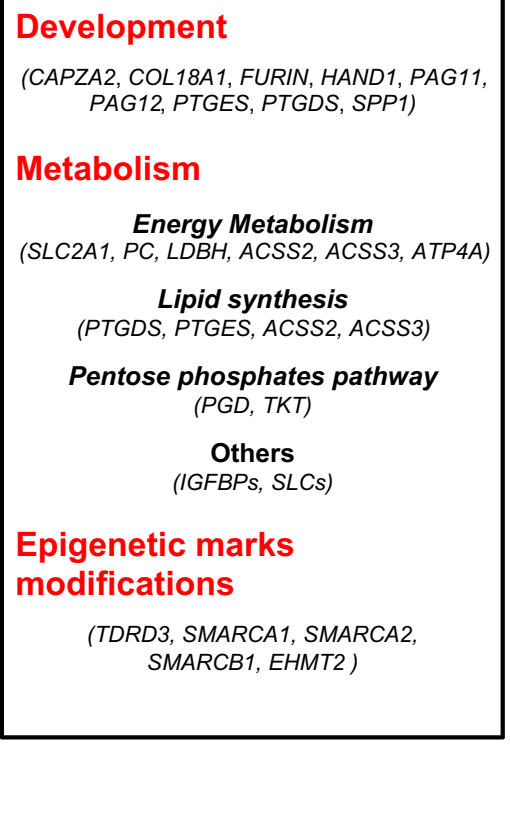

Development

2, COL18A1, FURIN, HAND1, PAG11, 12, PTGES, PTGDS, SPP1)

olism

Lipid synthesis

hosphates pathway (PGD, TKT)

Others

GFBPs, SLCs)

Epigenetic marks

modifications

SMARCB1, EHMT2 )

Fig. 6. Effect of the dam physiological status on molecular pathways expressed in D18 conceptus. Putative effect of energy balance and other factors related to dam physiological status on gene expression in EET at D18 of pregnancy. The energy balance could influence oocyte quality, oviductal environment as shown in Ref. 70, but also the uterine milieu, thus affecting on gene expression in the conceptus. A brief search of upstream regulators of the genes highlighted in this paper using Ingenuity Pathway Analysis highlighted some major "transversal" factors such as the PPAR-family genes, mediating the effect of nutrition on metabolism and epigenetic machinery (27). 
ing fertility, depending on the marks transmitted to the next generation (29).

\section{Conclusion}

In conclusion, despite similar morphological development in the conceptuses that survived up to D18, molecular characteristics of heifer conceptuses were consistently different from cow conceptuses. Most of these differences were strongly related to metabolic/hormonal patterns before insemination and during the free-life of the conceptuses, especially to circulating IGF-1 and NEFA concentrations, which were the parameters that were the most different between heifers and cows. We cannot exclude confounding factors to explain these relationships, but the pathways identified strongly sustain the hypothesis for an important role for dam energy metabolism on conceptus gene expression. Dam energy nutrient availability might have a direct effect on endometrium secretions, and this could affect conceptus metabolism and development. In our study, heifer conceptuses appeared to be engaged in more biosynthesis pathways and consequently seemed to be healthier and more able to continue their development than postpartum cow conceptuses.

\section{ACKNOWLEDGMENTS}

The authors gratefully acknowledge K. Hugot and J. Lecardonnel (CRBGADIE, INRA) for the production of the INRA 22K bovine array and the introduction to the Genepix software, P. Bardou (SIGENAE team, INRA) for the array data submission to the GEO database, F. Moreews (SIGENAE team, INRA) for the 2013 update of the array annotation, and L. Jouneau for the complementary annotation to bovine sequences. They also thank S. Camous and C. Ficheux for helpful advice on metabolic measurements, N. Da Silva for the determination of embryonic stages using PCR, and O. Sandra for support on validations by RT-qPCR.

Present addresses: P. Humblot, Dept. of Clinical Sciences, Div. of Reproduction, Swedish Univ. of Agricultural Sciences, SE-750 07 Uppsala, Sweden; C. Richard, 1) INRA, UMR 1198 Biologie du Développement et Reproduction, Jouy-en-Josas, France, and 2) Université Paris Est, ENVA, UMR 1198 Biologie du Développement et Reproduction, Maisons-Alfort, France.

\section{GRANTS}

This work received the financial support of the National Research Agency of France and APIS-GENE (GENANIMAL Program). D. Valour was a Ph.D. student with a DGER-INRA grant followed by a one-year grant thanks to the Reproseq project (INRA/UNCEIA). S. A. Degrelle was a "Conseil Régional d'Ile-de-France" postdoctoral fellow.

\section{DISCLOSURES}

No conflicts of interest, financial or otherwise, are declared by the author(s).

\section{AUTHOR CONTRIBUTIONS}

Author contributions: D.V., S.A.D., C.G.-D., E.C., C.R., and F.C. performed experiments; D.V., S.A.D., A.A.P., F.C., I.H., and B.G. analyzed data; D.V., S.A.D., A.A.P., C.G.-D., F.C., C.P., I.H., and B.G. interpreted results of experiments; D.V., S.A.D., I.H., and B.G. prepared figures; D.V., A.A.P., I.H., and B.G. drafted manuscript; D.V., S.A.D., A.A.P., C.G.-D., C.R., P.H., I.H., and B.G. edited and revised manuscript; D.V., S.A.D., A.A.P., C.G.-D., E.C., C.G.-J., C.R., F.C., P.H., C.P., I.H., and B.G. approved final version of manuscript; A.A.P., C.G.-J., P.H., C.P., I.H., and B.G. conception and design of research.

\section{REFERENCES}

1. Alves BC, Hossepian de Lima VF, Teixeira CM, Moreira-Filho CA. Use of primers derived from a new sequence of the bovine $\mathrm{Y}$ chromosome for sexing Bos taurus and Bos indicus embryos. Theriogenology 59: 1415-1419, 2003.
2. Arnold DR, Bordignon V, Lefebvre R, Murphy BD, Smith LC. Somatic cell nuclear transfer alters peri-implantation trophoblast differentiation in bovine embryos. Reproduction 132: 279-290, 2006.

3. Barnouin J, el Idilbi N, Chilliard Y, Chacornac JP, Lefaivre R. Automated micro-determination of bovine plasma 3-hydroxybutyrate without deproteinization. Ann Rech Vet 17: 129-139, 1986.

4. Baum B, Perrimon N. Spatial control of the actin cytoskeleton in Drosophila epithelial cells. Nat Cell Biol 3: 883-890, 2001.

5. Bazer FW, Kim J, Ka H, Johnson GA, Wu G, Song G. Select nutrients in the uterine lumen of sheep and pigs affect conceptus development. $J$ Reprod Dev 58: 180-188, 2012.

6. Bazer FW, Wu G, Johnson GA, Kim J, Song G. Uterine histotroph and conceptus development: select nutrients and secreted phosphoprotein 1 affect mechanistic target of rapamycin cell signaling in ewes. Biol Reprod 85: 1094-1107, 2011.

7. Berg DK, van Leeuwen J, Beaumont S, Berg M, Pfeffer PL. Embryo loss in cattle between Days 7 and 16 of pregnancy. Theriogenology 73: 250-260, 2010.

8. Betsha S, Hoelker M, Salilew-Wondim D, Held E, Rings F, GrosseBrinkhause C, Cinar MU, Havlicek V, Besenfelder U, Tholen E, Looft C, Schellander K, Tesfaye D. Transcriptome profile of bovine elongated conceptus obtained from SCNT and IVP pregnancies. Mol Reprod Dev 80: 315-333, 2013.

9. Betteridge KJ, Eaglesome MD, Randall GC, Mitchell D. Collection, description and transfer of embryos from cattle 10-16 days after oestrus. J Reprod Fertil 59: 205-216, 1980.

10. Boichard D, Barbat A, Briend M. Evaluation génétique des caractères de fertilité femelle chez les bovins laitiers. Renc Rech Rum 5: 103-106, 1998.

11. Brazma A, Hingamp P, Quackenbush J, Sherlock G, Spellman P, Stoeckert C, Aach J, Ansorge W, Ball CA, Causton HC, Gaasterland T, Glenisson P, Holstege FC, Kim IF, Markowitz V, Matese JC, Parkinson H, Robinson A, Sarkans U, Schulze-Kremer S, Stewart J, Taylor R, Vilo J, Vingron M. Minimum information about a microarray experiment (MIAME)-toward standards for microarray data. Nat Genet 29: 365-371, 2001.

12. Cagnone GL, Dufort I, Vigneault C, Sirard MA. Differential gene expression profile in bovine blastocysts resulting from hyperglycemia exposure during early cleavage stages. Biol Reprod 86: 50, 2012.

13. Cagnone GL, Sirard MA. Transcriptomic signature to oxidative stress exposure at the time of embryonic genome activation in bovine blastocysts. Mol Reprod Dev 80: 297-314, 2013.

14. Caraux G, Pinloche S. PermutMatrix: a graphical environment to arrange gene expression profiles in optimal linear order. Bioinformatics 21: 1280$1281,2005$.

15. Chagas LM, Bass JJ, Blache D, Burke CR, Kay JK, Lindsay DR, Lucy MC, Martin GB, Meier S, Rhodes FM, Roche JR, Thatcher WW, Webb R. Invited review: new perspectives on the roles of nutrition and metabolic priorities in the subfertility of high-producing dairy cows. $J$ Dairy Sci 90: 4022-4032, 2007.

16. Chang MC. Development of bovine blastocyst with a note on implantation. Anat Rec 113: 143-161, 1952.

17. Clemente M, Lopez-Vidriero I, O'Gaora P, Mehta JP, Forde N, Gutierrez-Adan A, Lonergan P, Rizos D. Transcriptome changes at the initiation of elongation in the bovine conceptus. Biol Reprod 85: 285-295, 2011.

18. Degrelle SA, Campion E, Cabau C, Piumi F, Reinaud P, Richard C, Renard JP, Hue I. Molecular evidence for a critical period in mural trophoblast development in bovine blastocysts. Dev Biol 288: 448-460, 2005.

19. Degrelle SA, Hennequet-Antier C, Chiapello H, Piot-Kaminski K, Piumi F, Robin S, Renard JP, Hue I. Amplification biases: possible differences among deviating gene expressions. BMC Genomics 9: 46, 2008.

20. Degrelle SA, Jaffrezic F, Campion E, Le Cao KA, Le Bourhis D, Richard C, Rodde N, Fleurot R, Everts RE, Lecardonnel J, Heyman Y, Vignon X, Yang X, Tian XC, Lewin HA, Renard JP, Hue I. Uncoupled embryonic and extra-embryonic tissues compromise blastocyst development after somatic cell nuclear transfer. PLoS One 7: e38309, 2012.

21. Degrelle SA, Le Cao KA, Heyman Y, Everts RE, Campion E, Richard C, Ducroix-Crepy C, Tian XC, Lewin HA, Renard JP, Robert-Granie C, Hue I. A small set of extra-embryonic genes defines a new landmark for bovine embryo staging. Reproduction 141: 79-89, 2011. 
22. Diskin MG, Morris DG. Embryonic and early foetal losses in cattle and other ruminants. Reprod Domest Anim 43, Suppl 2: 260-267, 2008.

23. Dray S, Dufour AB. The ade4 package: implementing the duality diagram for ecologists. J Stat Softw 22: 1-20, 2007.

24. Fenwick MA, Llewellyn S, Fitzpatrick R, Kenny DA, Murphy JJ, Patton J, Wathes DC. Negative energy balance in dairy cows is associated with specific changes in IGF-binding protein expression in the oviduct. Reproduction 135: 63-75, 2008.

25. Freret S, Grimard B, Ponter AA, Joly C, Ponsart C, Humblot P. Reduction of body-weight gain enhances in vitro embryo production in overfed superovulated dairy heifers. Reproduction 131: 783-794, 2006.

26. Freret S, Ponsart C, Rai DB, Jeanguyot N, Paccard P, Humblot P. Facteurs de variation de la fertilité en première insémination et des taux de mortalités embryonnaires en élevages laitiers Prim'Holstein. In: Rencontres Recherches Ruminants. Paris: 2006, p. 281-284.

27. Gabory A, Attig L, Junien C. Developmental programming and epigenetics. Am J Clin Nutr 94: 1943S-1952S, 2011.

28. González I, Déjean S, Martin P, Baccini A. CCA: an R package to extend canonical correlation analysis. J Stat Soft 23: 2008.

29. Gonzalez-Recio O, Ugarte E, Bach A. Trans-generational effect of maternal lactation during pregnancy: a Holstein cow model. PLoS One 7: e51816, 2012.

30. Grealy M, Sreenan JM. Effect of adenylyl cyclase activation on intracellular and extracellular cAMP and cGMP in preimplantation cattle blastocysts. J Reprod Fertil 116: 355-361, 1999.

31. Greenstein JS, Murray RW, Foley RC. Observations on the morphogenesis and histochemistry of the bovine preattachment placenta between 16 and 33 days of gestation. Anat Rec 132: 321-341, 1958.

32. Grimard B, Freret S, Chevallier A, Pinto A, Ponsart C, Humblot P. Genetic and environmental factors influencing first service conception rate and late embryonic/foetal mortality in low fertility dairy herds. Anim Reprod Sci 91: 31-44, 2006.

33. Hue I, Degrelle SA, Turenne N. Conceptus elongation in cattle: genes, models and questions. Anim Reprod Sci 134: 19-28, 2012.

34. Hue I, Renard JP, Viebahn C. Brachyury is expressed in gastrulating bovine embryos well ahead of implantation. Dev Genes Evol 211: 157159, 2001.

35. Humblot $\mathbf{P}$. Use of pregnancy specific proteins and progesterone assays to monitor pregnancy and determine the timing, frequencies and sources of embryonic mortality in ruminants. Theriogenology 1417-1433, 2001.

36. INRA. Alimentation des bovins, ovins et caprins. Versailles: Édition Quae, 2007, p. 307.

37. Kerr MK, Churchill GA. Experimental design for gene expression microarrays. Biostatistics 2: 183-201, 2001.

38. Lê Cao KA, González I, Déjean S. integrOmics: an R package to unravel relationships between two omics data sets Bioinformatics. Bioinformatics 25: 2855-2856, 2009.

39. Le Mezec P. Fertilité des principales races laitières: Bilan 1999-2008. Paris: Institut de l'élevage, 2010, p. 35.

40. LeBlanc S. Assessing the association of the level of milk production with reproductive performance in dairy cattle. J Reprod Dev 56, Suppl: S1-S7, 2010.

41. Ledoux D, Touze JL, Richard C, Ponter AA, Bosc MJ, Grimard B. Abnormal patterns of resumption of cyclicity after calving in Holstein cows: risk factors, relationships with the ultrasound appearance of the ovaries and with gestation failure after AI. Revue Méd Vét 162: 98-106, 2011.

42. Leese HJ, Sturmey RG, Baumann CG, McEvoy TG. Embryo viability and metabolism: obeying the quiet rules. Hum Reprod 22: 3047-3050, 2007.

43. Leroy JL, Opsomer G, Van Soom A, Goovaerts IG, Bols PE. Reduced fertility in high-yielding dairy cows: are the oocyte and embryo in danger? Part I. The importance of negative energy balance and altered corpus luteum function to the reduction of oocyte and embryo quality in highyielding dairy cows. Reprod Domest Anim 43: 612-622, 2008.

44. Leroy JL, Van Soom A, Opsomer G, Goovaerts IG, Bols PE. Reduced fertility in high-yielding dairy cows: are the oocyte and embryo in danger? Part II. Mechanisms linking nutrition and reduced oocyte and embryo quality in high-yielding dairy cows. Reprod Domest Anim 43: 623-632, 2008.

45. López-Gatius F, Yániz J, Madriles-Helm D. Effects of body condition score and score change on the reproductive performance of dairy cows: a meta-analysis. Theriogenology 59: 801-812, 2003.

46. Maddox-Hyttel P, Alexopoulos NI, Vajta G, Lewis I, Rogers P, Cann L, Callesen H, Tveden-Nyborg P, Trounson A. Immunohistochemical and ultrastructural characterization of the initial post-hatching development of bovine embryos. Reproduction 125: 607-623, 2003.
47. Maillo V, Rizos D, Besenfelder U, Havlicek V, Kelly AK, Garrett M, Lonergan P. Influence of lactation on metabolic characteristics and embryo development in postpartum Holstein dairy cows. J Dairy Sci 95: 3865-3876, 2012.

48. Mamo S, Mehta JP, Forde N, McGettigan P, Lonergan P. Conceptusendometrium crosstalk during maternal recognition of pregnancy in cattle. Biol Reprod 87: 6, 1-9, 2012.

49. Mamo S, Mehta JP, McGettigan P, Fair T, Spencer TE, Bazer FW, Lonergan P. RNA sequencing reveals novel gene clusters in bovine conceptuses associated with maternal recognition of pregnancy and implantation. Biol Reprod 85: 1143-1151, 2011.

50. Maruotti J, Munoz M, Degrelle SA, Gomez E, Louet C, Diez C, de Longchamp PH, Brochard V, Hue I, Caamano JN, Jouneau A. Efficient derivation of bovine embryonic stem cells needs more than active core pluripotency factors. Mol Reprod Dev 79: 461-477, 2012.

51. McAllister AJ. Is crossbreeding the answer to questions of dairy breed utilization? J Dairy Sci 85: 2352-2357, 2002.

52. Michel A, Ponsart C, Freret S, Humblot P. Influence de la conduite de la reproduction sur les resultats a l'insemination en periode de paturage. Rencontres Recherches Ruminants 10: 131-134, 2003.

53. Mishra VS, Henske EP, Kwiatkowski DJ, Southwick FS. The human actin-regulatory protein cap G: gene structure and chromosome location. Genomics 23: 560-565, 1994.

54. Morris DG, Humpherson PG, Leese HJ, Sreenan JM. Amino acid turnover by elongating cattle blastocysts recovered on days 14-16 after insemination. Reproduction 124: 667-673, 2002.

55. Nagatomo H, Kagawa S, Kishi Y, Takuma T, Sada A, Yamanaka KI, Abe Y, Wada Y, Takahashi M, Kono T, Kawahara M. Transcriptional wiring for establishing cell lineage specification at the blastocyst stage in cattle. Biol Reprod 88: 158, 2013.

56. Ponter AA, Guyader-Joly C, Nuttinck F, Grimard B, Humblot $\mathbf{P}$. Oocyte and embryo production and quality after OPU-IVF in dairy heifers given diets varying in their $n-6 / n-3$ fatty acid ratio. Theriogenology 78 : 632-645, 2012.

57. R Development Core Team. R: a language and environment for statistical computing. Vienna, Austria: R Foundation for Statistical Computing, 2011.

58. Richard C, Gelin V, Neveux A, Hue I, Heyman Y, Chavatte-Palmer P. Transcervical embryo collection in late stage in cattle. Eur Embryo Transf Assoc 29th Meeting. Istanbul, 2013, p. 194.

59. Rizos D, Carter F, Besenfelder U, Havlicek V, Lonergan P. Contribution of the female reproductive tract to low fertility in postpartum lactating dairy cows. J Dairy Sci 93: 1022-1029, 2010.

60. Rone MB, Fan J, Papadopoulos V. Cholesterol transport in steroid biosynthesis: role of protein-protein interactions and implications in disease states. Biochim Biophys Acta 1791: 646-658, 2009.

61. Royal M, Darwash A, Flint A, Webb R, Woolliams J, Lamming G. Declining fertility in dairy cattle: changes in traditional and endocrine parameters of fertility. Anim Sci 70: 487-501, 2000.

62. Sartori R, Bastos MR, Wiltbank MC. Factors affecting fertilisation and early embryo quality in single- and superovulated dairy cattle. Reprod Fertil Dev 22: 151-158, 2010.

63. Sinclair KD, Rooke JA, McEvoy TG. Regulation of nutrient uptake and metabolism in pre-elongation ruminant embryos. Reprod Suppl 61: 371$385,2003$.

64. Sorensen MK, Norberg E, Pedersen J, Christensen LG. Invited review: crossbreeding in dairy cattle: a Danish perspective. J Dairy Sci 91: 4116-4128, 2008.

65. Tamminga $\mathbf{S}$. The effect of the supply of rumen degradable protein and metabolisable protein on negative energy balance and fertility in dairy cows. Anim Reprod Sci 96: 227-239, 2006.

66. Thompson IM, Cerri RL, Kim IH, Ealy AD, Hansen PJ, Staples CR, Thatcher WW. Effects of lactation and pregnancy on metabolic and hormonal responses and expression of selected conceptus and endometrial genes of Holstein dairy cattle. J Dairy Sci 95: 5645-5656, 2012.

67. Thompson JG. In vitro culture and embryo metabolism of cattle and sheep embryos - a decade of achievement. Anim Reprod Sci 60-61: 263-275, 2000.

68. Touzard E, Reinaud P, Dubois O, Joly-Guyader C, Humblot P, Ponsart C, Charpigny G. Bovine pregnancy-associated glycoproteins are allocated to cotyledonary or intercotyledonary trophoblast according to their phylogenetic origin. Reprod Fertil Dev 25: 197-198, 2012.

69. Turenne N, Tiys E, Ivanisenko V, Yudin N, Ignatieva E, Valour D, Degrelle SA, Hue I. Finding biomarkers in non-model species: literature mining of transcription factors involved in bovine embryo development. BioData Min 5: 12, 2012. 
70. Valour D, Hue I, Degrelle S, Dejean S, Marot G, Dubois O, Germain G, Humblot P, Ponter A, Charpigny G, Grimard B. Preand post-partum mild underfeeding influences gene expression in the reproductive tract of cyclic dairy cows. Reprod Domest Anim 48: 484 499, 2013.

71. Vandesompele J, De Preter K, Pattyn F, Poppe B, Van Roy N, De Paepe A, Speleman F. Accurate normalization of real-time quantitative RT-PCR data by geometric averaging of multiple internal control genes. Genome Biol 3: RESEARCH0034, 2002.

72. Vejlsted M, Du Y, Vajta G, Maddox-Hyttel P. Post-hatching development of the porcine and bovine embryo-defining criteria for expected development in vivo and in vitro. Theriogenology 65: 153-165, 2006.

73. Walsh SW, Williams EJ, Evans AC. A review of the causes of poor fertility in high milk producing dairy cows. Anim Reprod Sci 123: 127-138, 2011.
74. Wathes DC, Cheng Z, Chowdhury W, Fenwick MA, Fitzpatrick R, Morris DG, Patton J, Murphy JJ. Negative energy balance alters global gene expression and immune responses in the uterus of postpartum dairy cows. Physiol Genomics 39: 1-13, 2009.

75. Wathes DC, Clempson AM, Pollott GE. Associations between lipid metabolism and fertility in the dairy cow. Reprod Fertil Dev 25: 48-61, 2012.

76. Wathes DC, Fenwick M, Cheng Z, Bourne N, Llewellyn S, Morris DG, Kenny D, Murphy J, Fitzpatrick R. Influence of negative energy balance on cyclicity and fertility in the high producing dairy cow. Theriogenology 68, Suppl 1: S232-S241, 2007.

77. Wiltbank MC, Souza AH, Carvalho PD, Bender RW, Nascimento AB. Improving fertility to timed artificial insemination by manipulation of circulating progesterone concentrations in lactating dairy cattle. Reprod Fertil Dev 24: 238-243, 2011.

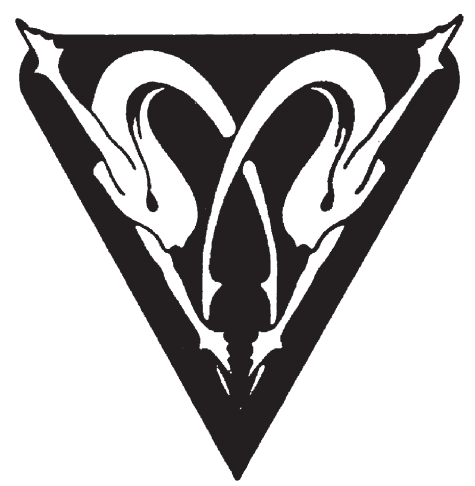

